\title{
An overview of recent bedrock mapping and follow-up petrological studies of the South Mountain Batholith, southwestern Nova Scotia, Canada
}

\author{
Michael A. MacDonald, Richard J. Horne, Michael C. Corey and Linda J. Ham \\ Nova Scotia Department of Natural Resources, P.O. Box 698, Halifax, Nova Scotia B3J 2T9, Canada
}

\author{
Date Received October 9, 1991 \\ Date Accepted March 12, 1992
}

\begin{abstract}
Recent detailed geological mapping has provided insight into the evolution of the South Mountain Batholith of southwestern Nova Scotia. Mapping has resulted in the delineation of 49 map units consisting of: biotite granodiorite, biotite monzogranite, muscovite-biotite monzogranite, coarse- and fine-grained leucomonzogranite and leucogranite; 49 map units have been assigned to thirteen plutons which have been grouped into two stages, including early stage 1 (mostly granodiorite and monzogranite) and late stage 2 (mostly monzogranite, leucomonzogranite, leucogranite). Follow-up petrographic and geochemical studies indicate a continuous sequence from least evolved biotite granodiorite to most evolved leucogranite.

In spite of a definitive sequence of emplacement for the plutons and their units, an evaluation of published geochronological data indicates that all plutons were intruded and crystallized during a very short time interval $(<5$ Ma) at ca. $370 \mathrm{Ma}$. Various structural characteristics, including the shape and distribution of plutons, the coincidence of several stage 2 plutons with major fault zones, and the orientation of primary and secondary structural features (e.g., megacryst alignment, joints, veins), indicate that the batholith was subjected to regional stresses associated with the waning stages of the Acadian Orogeny during intrusion.

The various rock types within the plutons have broadly similar compositions; however, detailed petrographic and geochemical studies have revealed unique compositional characteristics. These differences are explained by variations in protolith composition. Similarly, the style of mineralization in the sundry plutons is interpreted as reflecting the protolith composition and the physio-chemical conditions that prev ailed during their crystallization. Accordingly, the economic potential of the thirteen plutons must be evaluated individually.
\end{abstract}

Une nouvelle cartographie géologique détaillée a fourni des données sur l'évolution du batholite du mont South du sud-ouest de la Nouvelle-Écosse. La cartographie a permis de suivre 49 unités qui consistent en: granodiorite à biotite, monzogranite à biotite, monzogranite à biotite et muscovite, leucomonzogranite et leucogranite à grain grossier et fin; les 49 unités ont été assignées à treize plutons qui sont regroupés en deux stades: le stade 1, précoce (principalement granodiorite et monzogranite), et le stade 2, tardif (principalement monzogranite, leucomonzogranite et leucogranite). Les études pétrographiques et géochimiques d'appoint indiquent une suite continue allant des granodiorites à biotite, peu évoluées, aux leucogranites, les plus évolués.

En dépit d'une séquence d'intrusion bien définie pour les plutons et leurs unités, une évaluation des données géochronologiques publiées indique que tous les plutons se sont mis en place et ont cristallisé pendant un intervalle très court ( $<5 \mathrm{Ma})$, il y a environ $370 \mathrm{Ma}$. Diverses caractéristiques structurales, dont la forme et la distribution des plutons, la coïncidence de plusieurs plutons de stade 2 avec des zones de failles majeures et 1 'orientation des structures primaires et secondaires (e.g., alignement des mégacristaux, joints, veines) indiquent que le batholite était soumis, lors de sa mise en place, aux contraintes régionales associées aux stades finaux de l'orogénèse acadienne.

Les diverses lithologies à l'intérieur des plutons ont des compositions proches. Cependant, des études pétrographiques et géochimiques détaillées ont révélé des compositions particulières. Ces différences sont expliquées par des variations dans la composition des protolites. De la même manière, les patrons de minéralisations associées aux divers plutons sont interprétés comme reflètant la composition du protolite et les conditions physico-chimiques lors de la cristallisation. En conséquence, le potentiel économique des 13 plutons doit être évalué individuellement.

[Traduit par le journal]

\section{INTRODUCTION}

The South Mountain Batholith of southwestern Nova Scotia outcrops over approximately $7300 \mathrm{~km}^{2}$ and is the largest exposed peraluminous granitoid body in the Appalachian Orogen. Numerous studies relating to petrographic, geochemical and geochronological aspects of the batholith have been conducted during the past two decades (Clarke and Muecke, 1985; Clarke and Chatterjee, 1988, and references therein). These studies, and the resulting models for the origin and evolution of the batholith, were principally based upon the reconnaissance mapping of Smith (1974) and McKenzie (1974). 
In light of the discovery of the East Kemptville Sn deposit (Richardson et al., 1982), the Millet Brook U deposit (Chatterjee et al., 1985) and numerous Sn-W and U occurrences (O'Reilly et al., 1982; Chatterjee, 1983; Logothetis, 1985), a detailed mapping project was undertaken as part of the 1984-89 Canada-Nova Scotia Mineral Development Agreement. This paper outlines the mapping methodology, petrographic nomenclature and the hierarchial organization of rock units from this project and discusses the implications for previously proposed petrogenetic, metallogenic and emplacement models.

\section{Regional Geological Setting}

The South Mountain Batholith is located within the Meguma Terrane (Fig. 1), a suspect terrane of the Appalachian Orogen (Williams and Hatcher, 1983). Pre-granitic rocks in the Meguma Terrane include the Cambro-Ordovician Meguma Group and overlying Siluro-Devonian (Emsian) White Rock and Torbrook formations (Taylor, 1969). The former is comprised of Goldenville Formation psammites and conformably overlying Halifax Formation pelites, whereas the latter comprises mixed volcanic rocks, volcaniclastic and metasedimentary rocks. These rocks were regionally metamorphosed and deformed during the Mid- to Late Devonian Acadian Orogeny (Keppie and Dallmeyer, 1987; Muecke et al., 1988). Following the regional deformation and metamorphism, numerous meta- and peraluminous granitic intrusions, including the South Mountain Batholith, were emplaced ca. $370 \mathrm{Ma}$ (Fairbairn et al., 1964; Clarke and Halliday, 1980; Reynolds et al., 1981, 1987). The batholith is overlain by coarse clastic terrestrial sedimentary rocks of the Horton Group of Tournaissian age (Bell and Blenkinsop, 1960; Howie and Barss, 1975). Thus, the time of intrusion, crystallization and unroofing is bracketed between the Emsian and Tournaissian.

Recent work in the eastern Meguma Terrane now provides insight into its crustal stratigraphy at ca. $370 \mathrm{Ma}$. Giles and Chatterjee $(1986,1987)$ reported an ortho- and paragneiss complex with associated gabbroic intrusions that pierced the Meguma Group metasedimentary rocks near Liscomb. Geochronological studies $\left({ }^{40} \mathrm{Ar} /{ }^{39} \mathrm{Ar}\right)$ of the gneissic rocks (Kontak et al., 1990) indicate that they were emplaced in the waning stages of the Acadian Orogeny (ca. $370 \mathrm{Ma}$ ) along with the major granitoid plutons. Clarke et al. (in press) concluded, on the basis of detailed petrographic and geochemical studies, that the Liscomb gneisses are chemically distinct from the Meguma Group rocks and represent a sample of the lower crust.

Ruffman and Greenough (1990) reported a mafic dyke swarm, termed the "Weekend dykes", that outcrop in the eastern Meguma Terrane (Fig. 1). They noted that approximately half of the dykes contained exotic gneissic and (meta)plutonic xenoliths. Kempster et al. (1989) reported ${ }^{40} \mathrm{Ar} /{ }^{39} \mathrm{Ar}$ ages of $370 \pm 2$ and $367 \pm 2 \mathrm{Ma}$ for two of the Weekend dykes in the vicinity of Tangier (Fig. 1) suggesting that the dykes may have been emplaced synchronously with the Liscomb gneisses. Chatterjee and Giles (1988) and Eberz et al. $(1988,1991)$ conducted detailed petrological and geochemical studies of a suite of granulite xenoliths from one of these dykes near Tangier (Fig. 1) and concluded that the xenoliths represent upper crustal material from the Avalon Terrane that was rapidly subducted beneath the Meguma Terrane to lower crustal P-T conditions during the Mid- to Late Devonian.

\section{Previous Mapping in the South Mountain Batholith}

Several geological mapping projects have been conducted in the South Mountain Batholith and a list of previous workers with their respective subdivision criteria is presented in Table 1. Early mapping projects (e.g., Fairbault, 1908) delineated the boundaries of the batholith, but no attempt was made to subdivide the granitic rocks into lithotypes. Fairbault (1924) first delineated different types of granite in the vicinity of Mahone Bay based on the dominance of biotite over muscovite. Taylor (1969) reported the texture, dominant mica type (i.e., biotite versus muscovite) and the relative abundance of metasedimentary xenoliths for individual outcrops in the western part of the batholith. However, he did not use this information to subdivide the granitic rocks into mappable units. Subsequent mapping programmes employed various textural and mineralogical criteria to separate the rocks (Table 1). Several of these studies consisted of very detailed mapping in restricted areas (e.g., Smitheringale, 1973; Charest, 1976), although most were reconnaissance in nature and covered large regions (e.g., Smith, 1974; McKenzie, 1974). Keppie (1979) compiled the results of these previous studies and produced a general geology map (inset in Fig. 4) consisting of a three-fold classification scheme that included granodiorite, monzogranite and alaskite.

\section{Methodology}

Geological mapping was conducted by the authors during the 1985, 1986 and 1988 field seasons. Mapping commenced along all-weather and logging roads and easily accessible lakes and streams. Foot traverses were then used to supplement outcrop coverage in areas with poor access, diverse rock types or complex geology; helicopter traverses were used in remote regions. Several regions are uniformly blanketed by regional ground moraine and consequently have a very low outcrop density. Geological boundaries in these regions were partly or entirely delineated using till clast distribution in the ground moraine (Graves and Finck, 1988) and/or the results of airborne gamma-ray spectrometric surveys, in particular equivalent U/equivalent Th (O'Reilly et al., 1988).

Geological information recorded in the field included: (1) grain size, texture, colour and modal mineralogy of the major rock type(s); (2) orientation, size, spacing and type(s) of dykes, veins, joints, shear zones and faults; (3) orientation and degree of development of primary fabrics or mineral 


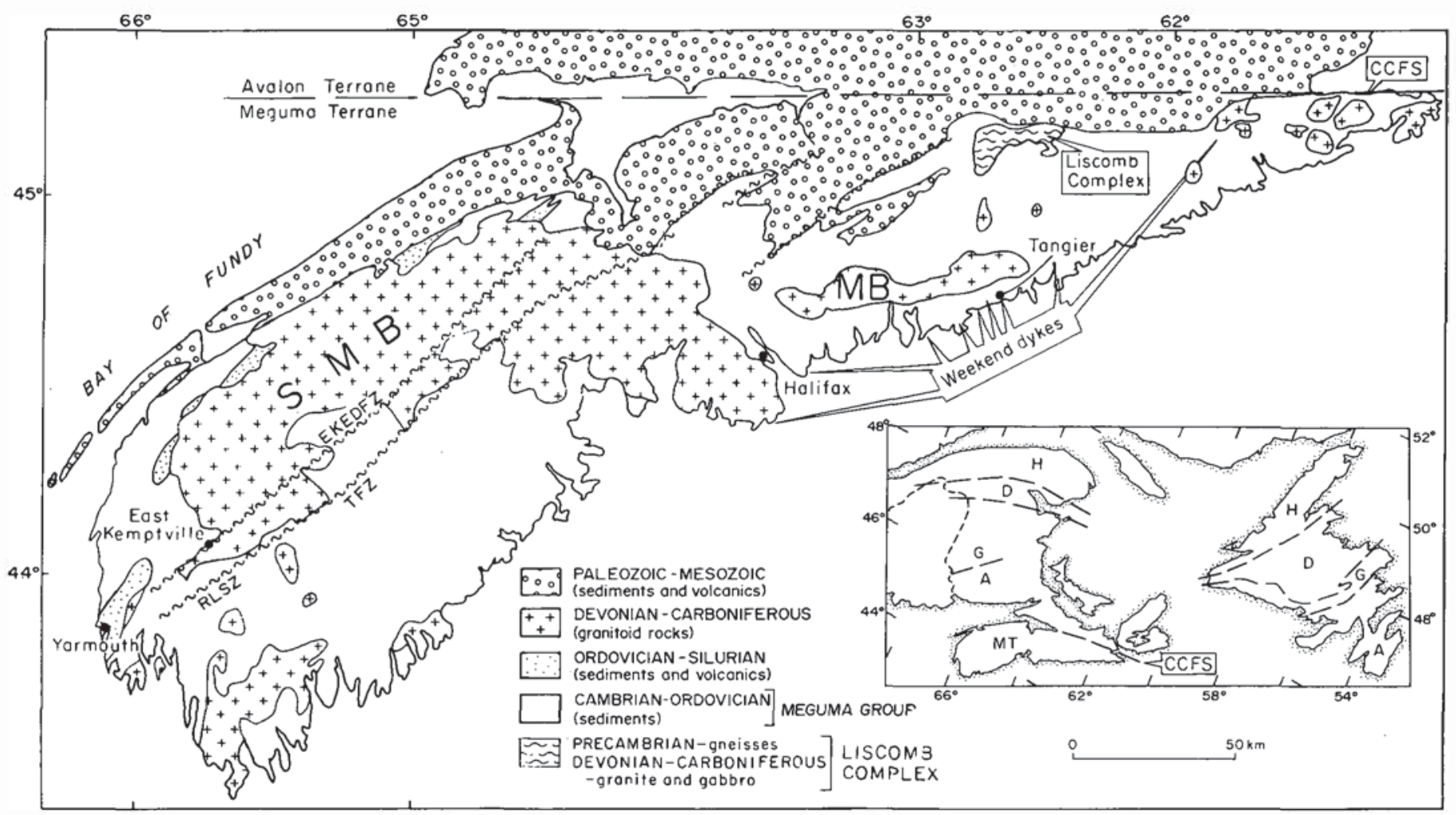

Fig. 1. Geological map of the Meguma Terrane showing the location of the South Mountain Batholith (SMB) and the Musquodoboit Batholith (MB). The boundary between the Meguma and Avalon terranes is marked by the Cobequid Chedabucto fault system (CCFS). The locations of the "Weekend dykes" of Ruffman and Greenough (1990), including the Tangier dyke of Chatterjee and Giles (1988), and the Liscomb complex (Giles and Chatterjee, 1986, 1987), are given. The locations of the Tobeatic fault zone (TFZ; Giles, 1985), East Kemptville-East Dalhousie fault zone (EKEDFZ; Horne et al., 1988) and Rushmere Lake shear zone (RLSZ; Smith, 1985) are given.

Table 1. Review of criteria for subdivision of granitic rocks of the South Mountain Batholith.

\begin{tabular}{|c|c|c|c|c|c|c|c|c|c|c|c|}
\hline \multirow[t]{3}{*}{ Author(s) } & \multicolumn{10}{|c|}{ CRITERIA } & \multirow[t]{3}{*}{ COMMENTS } \\
\hline & \multirow{2}{*}{ QAP } & \multirow{2}{*}{$\begin{array}{l}\text { GR } \\
\text { SIZE } \\
\end{array}$} & \multirow[t]{2}{*}{ TEX } & \multicolumn{5}{|c|}{ MODAL MINERALOGY } & \multirow{2}{*}{$\begin{array}{l}\text { PLAG } \\
\text { COMP }\end{array}$} & \multirow{2}{*}{$\begin{array}{l}\text { XEN } \\
\text { ABUND }\end{array}$} & \\
\hline & & & & BIOT & MUSC & CORD & GARN & MEGA & & & \\
\hline Faribault (1924) & & & & $\mathrm{x}$ & $\mathrm{x}$ & & & & & & 2 divisions: biot granite and musc granite \\
\hline Taylor (1969) & & & $\mathrm{x}$ & $\mathrm{x}$ & $\mathrm{x}$ & & & & & $\mathrm{x}$ & $\begin{array}{l}2 \text { divisions: biot granite and musc granite } \\
\text { with "porphyritic" (i.e. megacrystic) and } \\
\text { "xenolith" qualifiers }\end{array}$ \\
\hline $\begin{array}{l}\text { Smitheringale } \\
(1973)\end{array}$ & $\mathrm{x}$ & $\mathrm{x}$ & $\mathrm{x}$ & & & & & & & $\mathrm{x}$ & $\begin{array}{l}7 \text { divisions: (e.g. medium grained non- } \\
\text { porphyritic quartz monozonite) }\end{array}$ \\
\hline $\begin{array}{l}\text { Cormier and } \\
\text { Smith (1973): } \\
\text { Smith (1974, } \\
\text { 1979) }\end{array}$ & $\mathrm{x}$ & & $\mathrm{x}$ & $\mathrm{x}$ & $\mathrm{x}$ & & & & $\mathrm{x}$ & & $\begin{array}{l}4 \text { divisions: granodiorite: porphyritic } \\
\text { quartz monzonite: muscovite-biotite } \\
\text { granite: and alaskite }\end{array}$ \\
\hline $\begin{array}{l}\text { McKenzie (1974): } \\
\text { McKenzie and } \\
\text { Clarke (1975) }\end{array}$ & $\mathrm{x}$ & & $\mathrm{x}$ & $\mathrm{x}$ & $\mathrm{x}$ & & & & $\mathrm{x}$ & & $\begin{array}{l}\text { 3 divisions: granodiorite; adamellite } \\
\text { (i.e. monzogranite): and minor Intrusives } \\
\text { (further subdivided into porphyry. } \\
\text { alaskite and leucoadamellite) }\end{array}$ \\
\hline Charest (1976) & $\mathrm{x}$ & & $\mathrm{x}$ & $\mathrm{x}$ & $\mathrm{x}$ & & & & $\mathrm{x}$ & & $\begin{array}{l}5 \text { divisions: granodiorite: adamellite } \\
\text { (i.e. monzogranite); porphyry: } \\
\text { leucoadamellite; and mica aplite }\end{array}$ \\
\hline Present study & $\mathrm{x}$ & $\mathrm{x}$ & $\mathrm{x}$ & $\mathrm{x}$ & $\mathrm{x}$ & $\mathrm{x}$ & $\mathrm{x}$ & $\mathrm{x}$ & & & 6 main divisions (descriptions in text) \\
\hline
\end{tabular}

Abbreviations: QAP-modal proportions of quartz-alkali feldspar-plagioclase; GR SIZE-grain size; TEX-texture; BIOT-biotite; MUSC-muscovite; CORDcordierite; GARN-garnet: MEGA-feldspar megacrysts: PLAG COMP-An content of plagioclase; XEN ABUND-abundance of xenoliths.

alignment(s); (4) presence and style of mineralization and hydrothermal alteration; and (5) abundance and type of xenoliths (both metasedimentary and igneous). Large hand samples (approximately $2-10 \mathrm{~kg}$ ) were routinely collected at approxi- mately 1 to $2 \mathrm{~km}$ intervals along traverses in homogeneous rock units and more closely in heterogeneous rock units or when more than one rock type was encountered. Approximately 2500 samples were collected, all samples were slabbed 
and stained for alkali feldspar using sodium cobaltinitrate solution. Approximately 1500 of these 2500 samples were subsequently point counted ( $400-1000$ points/sample) using a binocular microscope and/or petrographic microscope, respectively. The entire sample collection has been archived in the Nova Scotia Department of Natural Resources storage facilities in Stellarton, Nova Scotia.

Data were recorded in the field on $1: 10,000$ scale colour air photos and compiled in the field onto $1: 15,840(1 "=1 / 4$ mile) scale Nova Scotia Department of Lands and Forest base maps. This information was subsequently compiled on 1:50,000 scale National Topographic Series planimetric base maps for publication. A total of fourteen bedrock geology maps have been released as Nova Scotia Department of Natural Resources published and/or open file maps. The locations of these map sheets along with the respective authors are given in Figure 2.

\section{Rock Classification Scheme}

The most widely accepted classification scheme for igneous rocks is that of Streckeisen (1976). This method is based upon the modal proportions of quartz, alkali feldspar and plagioclase and is particularly useful in igneous terranes with widely ranging compositions. For example, in the Sierra Nevada Batholith of California where compositions range from gabbro to leucogranite (Bateman, 1988), or in the Coastal Batholith of Peru where rock types range from gabbro to monzogranite (Cobbing et al., 1981). Previous studies of the batholith (Smith, 1974; McKenzie and Clarke, 1975) noted a comparatively restricted range from granodiorite to monzogranite. Thus, strict adherence to the classification scheme of Streckeisen (1976) would yield only two rock types in most of the batholith. Therefore, a modified Streckeisen (1976) classification scheme was developed based upon the results of preliminary and past mapping projects (MacDonald, 1985; Table 1). Granitic rocks are divided on the basis of: (1) the modal proportions of quartz, alkali feldspar and plagioclase; (2) grain size (fine $<0.1 \mathrm{~cm}$; medium 0.1-0.5 cm; coarse $>0.5 \mathrm{~cm}$ ); (3) texture; and (4) the modal proportion of muscovite and the combined mafic minerals (biotite, cordierite, garnet; Table 1).

Several terms have been adopted and/or modified for use in this project. These include the compositional terms: leucomonzogranite - mostly monzogranite, and subordinate syenogranite, containing 2 to $6 \%$ combined mafic minerals; and leucogranite - monzogranite, syenogranite or alkali feldspar granite with $<2 \%$ combined mafic minerals; and the textural terms megacryst (adj. megacrystic) - a non-genetic term for a large (generally $2.5-7 \mathrm{~cm}$ ) crystal (mostly alkali feldspar and lesser plagioclase) in a medium- to coarsegrained rock; and porphyry (adj. porphyritic) - a granitic rock with predominantly fine-grained groundmass and medium- to coarse-grained phenocrysts.

The batholith was divided into six main rock types using the above classification scheme. These include biotite granodiorite, biotite monzogranite, muscovite-biotite monzogranite,

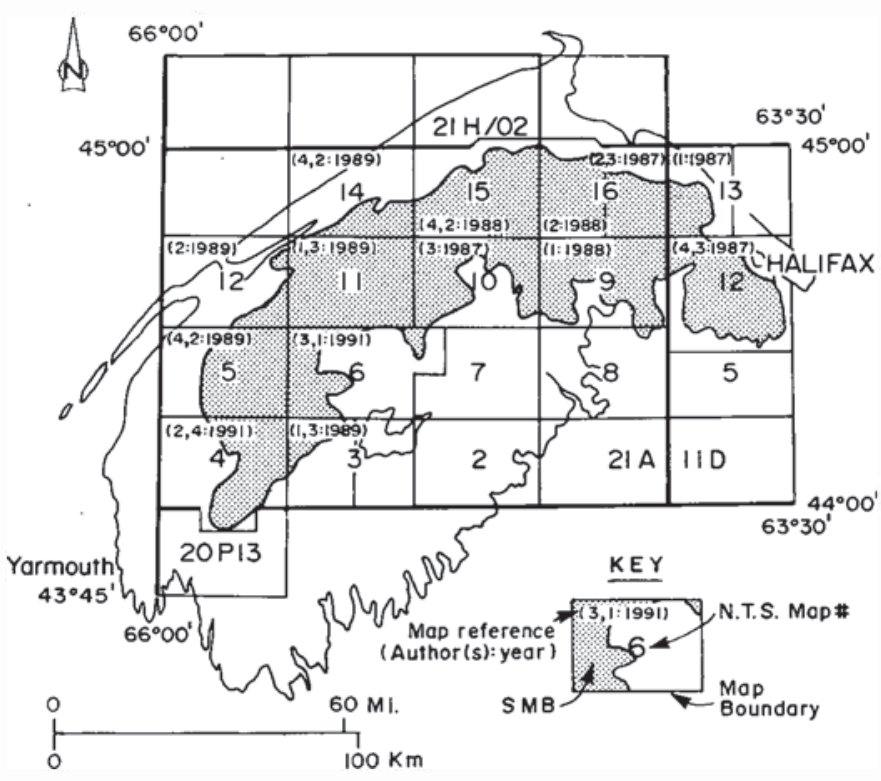

Fig. 2. Reference map for the fourteen 1:50,000 scale geological maps produced during the 1984-1989 mapping project. The map boundary is given for each of the National Topographic series maps, along with the respective author(s) and the year the map was published. Full citations are given in the references. Note that authors were ordered alphabetically and coded with numbers, including: (1) M.C. Corey; (2) L.J. Ham; (3) R.J. Horne; (4) M.A. MacDonald.

coarse-grained leucomonzogranite, fine-grained leucomonzogranite and leucogranite. The distribution of these rock types is given in Figure 3. An inset of the detailed geology of the East Kemptville area on this figure illustrates the increased geological information available on the series of $1: 50,000$ scale maps. General petrographic and geochemical features of these rock types are summarized below.

In addition to the six main rock types, several small bodies $\left(<100 \mathrm{~m}^{2}-1 \mathrm{~km}^{2}\right)$ of fine-grained, often porphyritic, granodiorite and monzogranite with a high percentage of biotite and common metasedimentary xenoliths, termed mafic porphyry, have been delineated. The nature and distribution of these volumetrically minor rocks is outlined in MacDonald et al. $(1987,1988)$ and will not be discussed in this paper.

\section{Hierarchial Organization of Rock Units and Results of Mapping}

The batholith comprises hundreds of granitic bodies that must be placed into a hierarchial system before larger problems, such as emplacement history or petrogenesis, can be dealt with effectively. The following section outlines our system for organization of granitic rocks.

\section{Map Body}

A single body of intrusive rock that is continuous is termed a map body. Contacts with surrounding igneous rocks are either intrusive or gradational. The map body of this study 


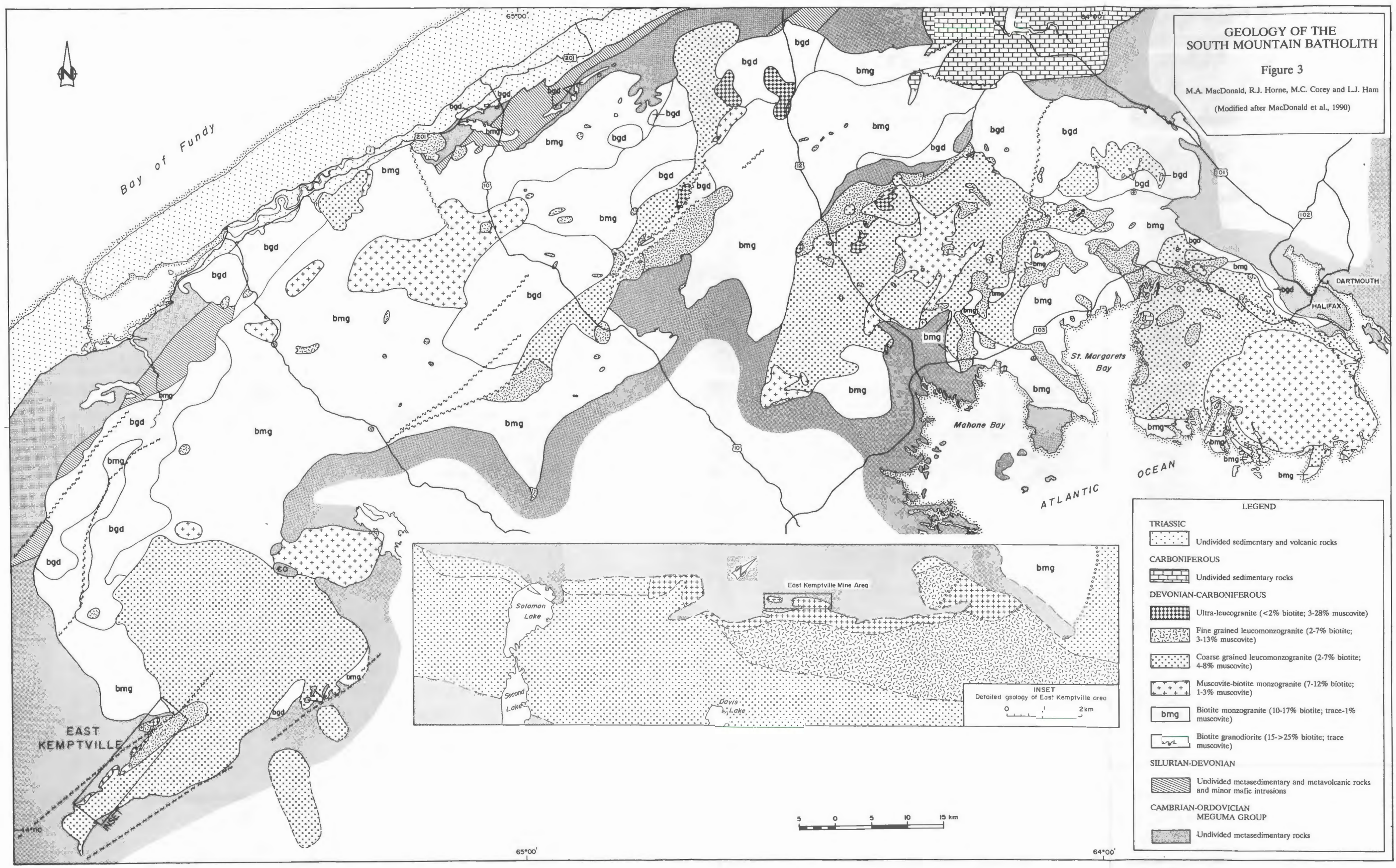

Fig. 3. Geological map of the South Mountain Batholith and surrounding rocks (1:250,000 scale) showing the distribution of the six main granitic rock types. Geological map of the East Kemptville area (inset at bottom) highlights the increased detail available in the series of 1:50,000 scale maps outlined in Figure 2 . 
corresponds to "pulse" of Cobbing et al. (1981), "pluton" of Bateman (1988) and is equivalent to "member" among stratified sedimentary rocks (Table 2). Our mapping has delineated 260 individual map bodies, ranging in size from $<1$ to $>1,000 \mathrm{~km}^{2}$, within the contiguous South Mountain Batholith. Many small bodies $\left(<1 \mathrm{~km}^{2}\right)$ could not be portrayed in Figure 3 because of their size. Full descriptions of all map bodies are given in the series of 1:50,000 scale geological maps outlined in Figure 2.

\section{Map Unit}

Two or more map bodies composed of similar texture, grain size, modal mineralogy and composition (i.e., modal quartz-alkali feldspar-plagioclase) with similar field relations with surrounding igneous rocks in approximately the same geographical region are grouped into map units. Each map unit was assigned a place name followed by the most abundant rock type in the map unit, for example the Tantallon leucomonzogranite (MacDonald and Horne, 1987) or the Salmontail granodiorite (Ham and Horne, 1987). A few map units consist of a single map body (generally $>100 \mathrm{~km}^{2}$ ), for example the Whale Lake monzogranite (Horne, 1987). The map unit of this study corresponds to the "unit" of Cobbing $e t$ al. (1981), the "lithodeme" of Bateman (1988), and is equivalent to "formation" among stratified sedimentary rocks (Table 2). A total of 49 map units were identified in the batholith. A full description of the textural/mineralogical aspects and field relations of the 49 map units would be beyond the scope of this paper. Once again, for additional information the reader is referred to the $1: 50,000$ scale geological maps with marginal notes (Fig. 2).

\section{Pluton}

One or more map units may be assigned to a single pluton based upon systematic mineralogical and/or chemical variation (i.e., zoning), similar field relationships with surrounding plutons, and unique textural or mineralogical characteris- tics. The assignation of map units to plutons is dependant upon an extensive petrographic and geochemical data base. At present, the data base is limited for specific regions of the batholith. Consequently, the number and specific boundaries of the plutons are tentative and may be revised as additional data become available. The pluton of this study corresponds to the "pluton" of Cobbing et al. (1981), the "intrusive suite" of Bateman (1988), and is equivalent to "group" among stratified sedimentary rocks (Table 2 ).

A total of thirteen plutons were outlined in the batholith. A map showing their locations is given in Figure 4 and a list of select features is given in Table 3. The thin lines within individual plutons in Figure 4 are generalized compositional isopleths (no units of measure) determined from point counting and whole rock geochemistry. The arrows that are oriented perpendicular to the isopleths indicate increasing differentiation index. The plutons can be divided into early stage 1 , comprising mostly granodiorite and monzogranite, and late stage 2, comprising monzogranite, leucomonzogranite and leucogranite. The two stages are equivalent to the "superunits" of Cobbing et al. (1981) and "super group" among stratified sedimentary rocks. The stages from this study may also be equivalent to "super suite" in the hierarchial scheme used by Bateman (1988). General observations regarding the nature, distribution and differences between the stage 1 and 2 plutons include: (1) stage 2 plutons invariably intrude stage 1 plutons; (2) the overall size range for stage 1 and 2 plutons is 30 to $2460 \mathrm{~km}^{2}$; (3) one stage 1 and five stage 2 plutons are compositionally unzoned whereas several stage 1 and 2 plutons display normal and/or reverse zoning; (4) stage 1 plutons have elliptical shapes and are oriented to the northeast whereas several stage 2 plutons are crudely circular in shape; (5) all stage 1 and five of the eight stage 2 plutons are partially bounded by faults. In fact, the East Dalhousie pluton is mostly fault-bounded; (6) prominent northeast-trending primary flow features (schlieren, parallel alignment of megacrysts/xenoliths) are common in stage 1 plutons whereas they are variably developed (non-existent to strong) with erratic or concentric orientations in stage 2 plutons.

Table 2. Summary of the hierarchial organization of rocks in the South Mountain Batholith. Hierarchial schemes from the western Cordillera of northern Peru (Cobbing et al., 1981), Sierra Nevada Batholith of California (Bateman, 1988) and stratified sedimentary rocks are also included.

\begin{tabular}{||l|c|c|c|c||}
\hline \hline \multicolumn{1}{|c|}{ SMB } & \# Present & Cobbing et al. (1981) & Bateman (1988) & $\begin{array}{c}\text { Stratified sedimentary } \\
\text { rocks }\end{array}$ \\
Map body & 260 & pulse & pluton & member \\
Map unit & 49 & unit & lithodeme & formation \\
Pluton & 13 & pluton & intrusive suite & group \\
Stage & 2 & super unit & super suite & super group \\
\hline
\end{tabular}




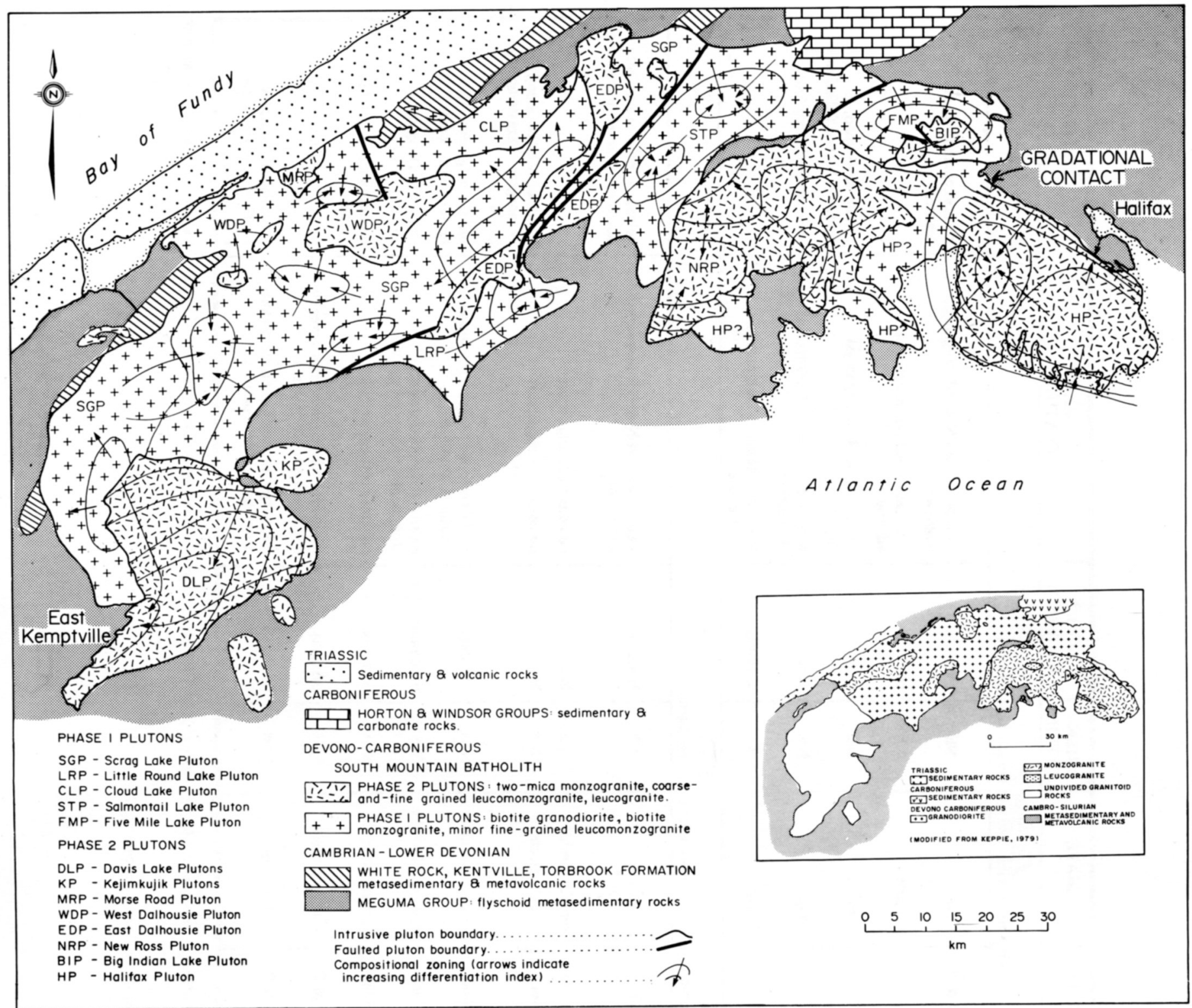

Fig. 4. Geological map of the South Mountain Batholith showing the location of the five stage 1 and eight stage 2 plutons. Heavy lines at pluton boundaries indicate faulted contacts whereas thinner lines indicate predominantly intrusive contacts (may be gradational in part). Thin lines within the individual plutons indicate compositional isopleths that were determined from point counting stained rock slabs and/or geochemical data. Arrows indicate increasing differentiation index. Areas of both normal and reverse compositional zoning (differentiation index increases and decreases, respectively, toward the core of the pluton) are evident in both stage 1 and 2 plutons. In fact, several plutons such as the Halifax and New Ross plutons, have both normal and reverse compositional zoning. Inset at lower right shows the previous geological map (Keppie, 1979).

\section{Petrography}

All granitic rocks contain essential quartz, alkali feldspar and plagioclase (QAP). A contoured density plot of 452 representative QAP determinations from the entire batholith is given in Figure 5A. The bulk of the batholith is composed of monzogranite and, to a lesser extent, granodiorite with minor tonalite and syenogranite. It should be noted that Streckeisen (1976; Fig. 5B) grouped plagioclase of $\mathrm{An}_{\text {s }}$ composition with alkali feldspar. Detailed petrographic studies (Smith et al., 1986; MacDonald and Horne, 1988) report albitic plagioclase in leucomonzogranite rocks of the batho- lith. In fact, recent studies of leucogranitic rocks by Kontak (1990) and MacDonald and Clarke (1991) noted the anorthite content of plagioclase in most leucogranite bodies is $\angle \mathrm{An}_{\mathrm{s}}$. Grouping this plagioclase with alkali feldspar would shift the compositions toward the alkali feldspar-quartz join of the QAP diagram, that is, into the syenogranite and alkali feldspar fields. The determination of the exact amount of albite with $\mathrm{An}_{\text {s }}$ would require extensive petrographic/microprobe analyses. Therefore, for the purpose of developing a field method for rock classification, we have grouped all plagioclase compositions together. 
Table 3. Summary of selected features of Phase 1 and Phase 2 plutons.

\begin{tabular}{|c|c|c|c|c|c|c|c|c|}
\hline PLUTON NAME & $\begin{array}{l}\text { AREA } \\
\left(K^{2}\right)\end{array}$ & ROCK TYPES ( $\%$ of Pluton) & ZONING & SHAPE & $\begin{array}{l}\text { ORIEN- } \\
\text { TATION }\end{array}$ & $\begin{array}{c}\text { FAULT } \\
\text { BOUNDED }\end{array}$ & $\begin{array}{c}\text { PRIMARY } \\
\text { FEATURES }\end{array}$ & COMMENTS \\
\hline \multicolumn{9}{|c|}{$\begin{array}{l}\text { EARLY } \\
\text { Stage } 1 \text { Plutons - dominantly biotite granodiorite and biotite monzogranite with minor fine-grained leucomonzongranite }\end{array}$} \\
\hline Scrag Lake WEST & 2460 & $\operatorname{BMG}(79) ; \mathrm{BGD}(21)$ & $N \& R$ & elongate & NE & partially & $\begin{array}{l}\text { well developed } N \text { \& NE megacryst } \\
\text { alignment }\end{array}$ & $\begin{array}{l}\text { several compositional } \\
\text { "centres" }\end{array}$ \\
\hline Little Round Lake & 230 & BMG $(\approx 100)$ & $\mathbf{R}$ & elongate & NE & partially & $\begin{array}{l}\text { well developed NE megacryst } \\
\text { alignment }\end{array}$ & \\
\hline Cloud Lake & 250 & BMG(95); BGD(5) & None & elongate & NE & partially & $\begin{array}{l}\text { pervasive NE \& E megacryst } \\
\text { alignment }\end{array}$ & $\begin{array}{l}\text { locally developed, E- } \\
\text { trending biotite foliation }\end{array}$ \\
\hline Salmontail Lake & 650 & $\begin{array}{l}\text { BMG(91); BGD(8); } \\
\text { FGLMG(1) }\end{array}$ & $\mathrm{N}$ & elongate & NE & partially & $\begin{array}{l}\text { weakly developed NE megacryst } \\
\text { alignment }\end{array}$ & two compositional "centres" \\
\hline $\begin{array}{r}\text { Five Mile Lake } \\
\text { EAST }\end{array}$ & 270 & $\mathrm{BGD}(\approx 100)$ & $\mathbf{R}$ & elliptical & $\mathrm{E}$ & partially & $\begin{array}{l}\text { moderate megacryst alignment - } \\
\text { erratic orient. }\end{array}$ & \\
\hline \multicolumn{9}{|c|}{$\begin{array}{l}\text { LATE } \\
\text { Stage } 2 \text { Plutons - dominantly muscovite-biotite monzogranite and leucomonzogranite with minor ultra-leucogranite }\end{array}$} \\
\hline Davis Lake WEST & 820 & $\begin{array}{l}\text { CGLMG(93); FGLMG(3); } \\
\text { BGD(1); BMG(1); } \\
\text { MBMG(1); LG(<1) }\end{array}$ & $\mathrm{N}$ & $\begin{array}{l}\text { circular \& } \\
\text { elongate* }\end{array}$ & *NE & *partially & $\begin{array}{l}\text { well developed } \mathrm{N} \& \mathrm{NE} \text { megacryst } \\
\text { alignment }\end{array}$ & $\begin{array}{l}\text { *elongate portion partially } \\
\text { bounded by intense shearing }\end{array}$ \\
\hline Kejimkujik & 80 & MBMG $(\approx 100)$ & None & roughly circular & N/A & No & no consistent alignment & \\
\hline Morse Road & 30 & CGLMG(85);MBMG(15) & None & roughly circular & N/A & No & no consistent alignment & $\begin{array}{l}\text { bands of MBMG along E + } \\
\text { W margins suggests normal } \\
\text { zoning }\end{array}$ \\
\hline West Dalhousie & 220 & $\operatorname{MBMG}(\approx 100)$ & None & roughly circular & N/A & partially & $\begin{array}{l}\text { well developed megacryst alignment - } \\
\text { erratic orientation }\end{array}$ & $\begin{array}{l}\text { unique megacryst-rich } \\
\text { texture with "bladed" biotite }\end{array}$ \\
\hline East Dalhousie & 310 & $\begin{array}{l}\text { CGLMG(52);FGLMG(34); } \\
\text { ULG(10); MBMG(4) }\end{array}$ & None & narrow dyke-like & NE & predominantly & $\begin{array}{l}\text { locally-developed megacryst } \\
\text { alignment - erratic orientation }\end{array}$ & $\begin{array}{l}\text { emplaced along major } \\
\text { structure }\end{array}$ \\
\hline Big Indian Lake & 40 & $\begin{array}{l}\text { CGLMG(81); FGLMG(71); } \\
\text { BMG(2) }\end{array}$ & None & circular/irregular & N/A & partially & no consistent alignment & $\begin{array}{l}\text { ubiquitous metasomatic } \\
\text { garnet }\end{array}$ \\
\hline New Ross & 870 & $\begin{array}{l}\text { CGLMG(59); FGLMG(28); } \\
\text { MBMG(12); ULG(2) }\end{array}$ & $N \& R$ & roughly circular & N/A & partially & $\begin{array}{l}\text { megacryst alignment defines weakly- } \\
\text { developed circular patterns }\end{array}$ & overall reverse zonation \\
\hline Halifax & 1060 & $\begin{array}{l}\text { CGLMG(38); MBMG(33); } \\
\text { BMG(13); FGLMG(12); } \\
\text { BGD(4) }\end{array}$ & $N \& R$ & roughly circular & N/A & no & $\begin{array}{l}\text { megacryst alignment defines weakly- } \\
\text { developed circular patterns }\end{array}$ & $\begin{array}{l}\text { gradational contact with } \\
\text { BMG to west (separate } \\
\text { Phase I pluton?) }\end{array}$ \\
\hline
\end{tabular}

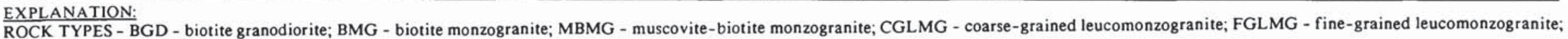
ULG - ultra-leucogranite.

ZONING - $\mathrm{N}$ - normal; $\mathrm{R}$ - reverse

ORIENTATION - refers to direction of long axis of pluton (if applicable); N/A - not applicable 

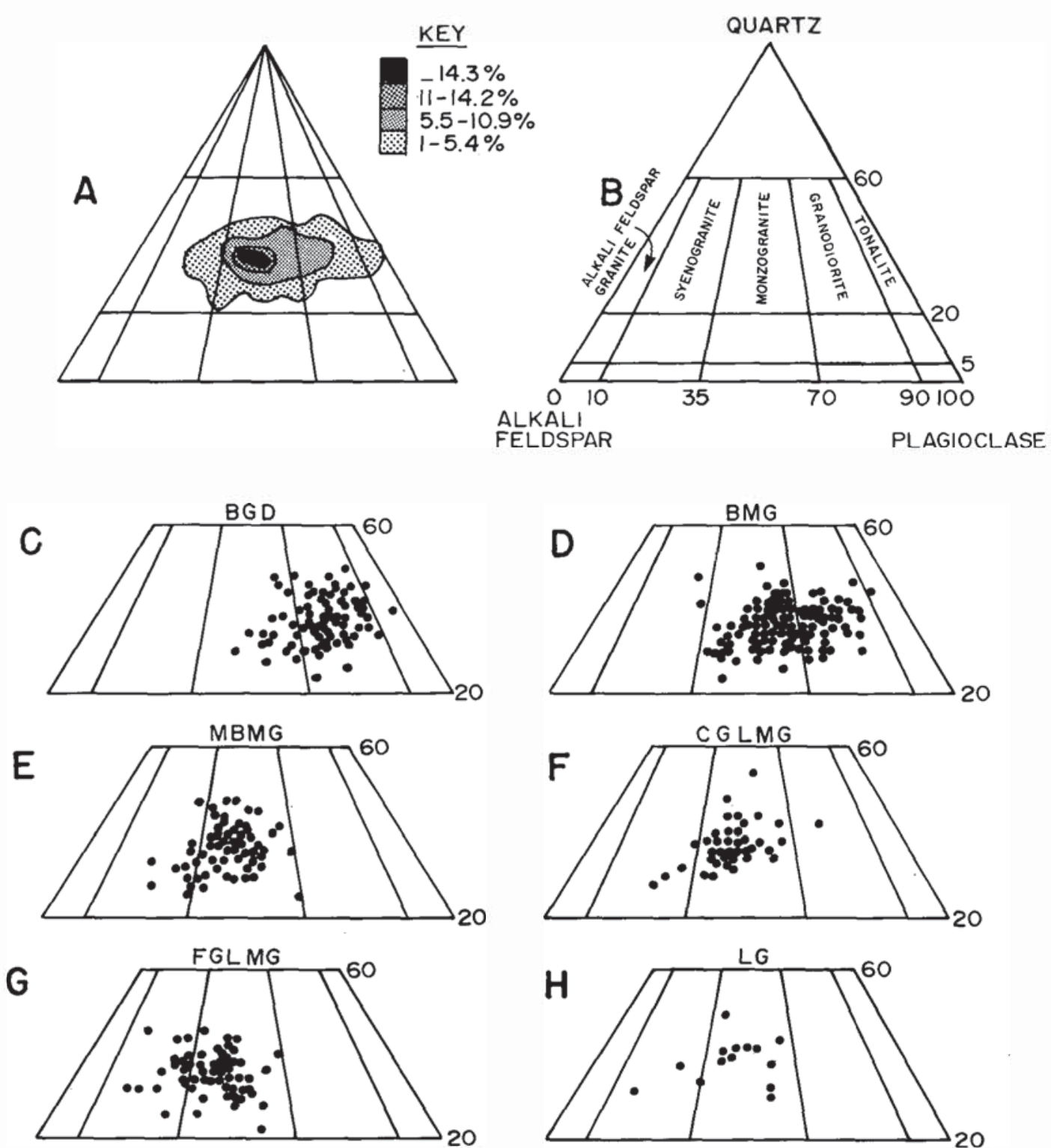

Fig. 5 (A) Contoured QAP plot of 452 representative samples from the batholith indicating a predominantly monzogranitic-granodioritic composition; (B) fields after Streckeisen (1976); QAP plots of representative samples from (C) biotite granodiorite (BGD); (D) biotite monzogranite (BMG); (E) muscovite-biotite monzogranite (MBMG); (F) coarse-grained leucomonzogranite (CGLMG); (G) finegrained leucomonzogranite (FGLMG); (H) leucogranite (LG).

Modal plots for the six major rock types for the entire batholith are given in Figure 5C-H. The wide degree of scatter within each rock type can be attributed to compositional variation, textural heterogeneities, and varying degrees of metasomatism (e.g., K-feldspathization, albitization) both within, and between, the various map units. In addition, counting error and operator bias presumably contribute to the degree of scatter, albeit of an unknown amount. It is apparent from the individual plots in Figure 5 that $\mathrm{A} / \mathrm{P}$ increases from biotite granodiorite to fine-grained leucomonzogranite and leucogranite.

A summary of the overall textural and petrographic characteristics of the six main rock types is given in Table 4 . Systematic textural variations are common to all rock types throughout the entire batholith. For example, most granodi- orite, monzogranite and coarse-grained leucomonzogranite units are medium- to coarse-grained with megacrystic (Plate 1a) or seriate (Plate 1b) textures. As noted above, many units display parallel alignment of alkali feldspar and, to a lesser extent, plagioclase megacrysts (Plate 1c). In contrast, finegrained leucomonzogranite and leucogranite units are predominantly fine- to medium-grained with mostly equigranular (Plates 1d,e), porphyritic (Plates 1f,g) and more rarely coarse-grained pegmatitic (Plate $1 \mathrm{~h}$ ) textures.

Systematic petrographic variations noted throughout the batholith define a sequence from least evolved granodiorite to most evolved leucogranite. These variations include: (1) biotite (Plate 2a) with inclusions of apatite, zircon (Plate 2b), monazite \pm xenotime \pm epidote \pm titanite decreases from $>25 \%$ in some granodiorite units to absent in several leu- 
Table 4. Description of major rock types in the South Mountain Batholith.

\begin{tabular}{|c|c|c|c|c|c|c|c|c|c|c|c|}
\hline ROCK TYPE & $\%$ of SMB & $\begin{array}{l}\text { GRAIN } \\
\text { SIZE }\end{array}$ & $\begin{array}{l}\text { DOMINANT } \\
\text { TEXTURES }\end{array}$ & $\begin{array}{c}\text { BIOTITE } \\
\%\end{array}$ & $\begin{array}{l}\text { MUSCOVITE } \\
\% \quad \text { Type }\end{array}$ & $\begin{array}{l}\text { PLAGIOCLASE } \\
\text { An } \quad \text { Zoning }\end{array}$ & $\begin{array}{c}\text { K-SPAR } \\
\text { EXSOL }\end{array}$ & $\underset{\%}{\mathrm{CORD}}$ & $\begin{array}{c}\text { AND } \\
\%\end{array}$ & $\begin{array}{c}\text { TOPAZ } \\
\%\end{array}$ & XENOLITHS \\
\hline Leucogranite & $0.7 \%$ & $f-m(c)$ & $\begin{array}{l}\text { porp, equi, } \\
\text { pegm }\end{array}$ & $0-2$ & euh > & unzoned & $\begin{array}{l}\text { non- } \\
\text { exsolved }\end{array}$ & tr. & $0-2$ & $0-8$ & none \\
\hline $\begin{array}{l}\text { Coarse-grained } \\
\text { leucomonzogranite }\end{array}$ & $21.8 \%$ & $m-c(f)$ & mega, seri & $2-7$ & $\begin{array}{r}\text { repl> } \\
\text { euh }\end{array}$ & $\begin{array}{r}\text { zoneds } \\
\text { unzoned }\end{array}$ & $\begin{array}{l}\text { patch }>\text { rod } \\
\& \text { bead } \\
\text { perthite }\end{array}$ & tr -5 & $0-\mathrm{tr}$ & 0 & rare \\
\hline Biotite Monzogranite & $52.2 \%$ & $m-c(f)$ & mega, seri & $10-17$ & $t r-1$ & & & $\mathrm{tr}-1$ & 0 & 0 & $\begin{array}{l}\text { common- } \\
\text { abundant }\end{array}$ \\
\hline Biotite granodiorite & $9.6 \%$ & $m-c(f)$ & mega, seri & $15>25$ & repl & $\begin{array}{l}<5- \\
35\end{array}$ & $\begin{array}{l}\text { rod \& } \\
\text { bead } \\
\text { perthite }\end{array}$ & tr. & 0 & 0 & abundant \\
\hline
\end{tabular}

EXPLANATION: GRAIN SIZE - $\mathrm{f}$ - fine $(<0.1 \mathrm{~cm}), \mathrm{m}$ - medium $(0.1-0.5 \mathrm{~cm}), \mathrm{c}$ - coarse $(>0.5 \mathrm{~cm})$ brackets denote minor occurrence

DOMINANT TEXTURE - equi - equigranular, porp. - porphyritic, pegm - pegmatitic, mega - megacrystic, seri - seriate, listed in descending order of importance BIOTITE, MUSCOVITE, CORD (CORDIERITE), AND (ANDALUSITE), TOPAZ \% - modal determinations from point counting ( 500 - 1000 points) of stained rock slabs and thin sections

MUSCOVITE TYPE - euh - euhedral (primary?), repl - replacement (secondary)

PLAGIOCLASE An - anorthite content (from microprobe analysis)

K-SPAR EXSOL - alkali feldspar exsolution textures

XENOLITHS - abundance of metasedimentary xenoliths: abundant - several in all outcrop; common - a few in most outcrop; rare - minor occurrence in some outcrop.

cogranite units; (2) muscovite increases from trace amounts in most granodiorite units to $>25 \%$ in several metasomatized leucogranite units; (3) muscovite generally occurs as anhedral grains replacing feldspar (Plate $2 c$ ) in granodiorite units to euhedral to subhedral grains (primary magmatic?; Plate $2 \mathrm{~d})$ in several fine-grained leucomonzogranite and leucogranite units; (4) cordierite (Plate 2e) and pinite/muscovite pseudomorphs (Plate 2f) occur in minor amounts in most units, but is most abundant in monzogranite and coarsegrained leucomonzogranite units where it may exceed 5\%; (5) alkali feldspar is invariably perthitic with rod, bleb, flame and film exsolution (Plate $2 \mathrm{~g}$ ) dominant in granodioritic and monzogranitic rocks, whereas patch-type perthite (Plate $2 \mathrm{~h}$ ) is more common in leucomonzogranite units. In most leucogranite units the alkali feldspar rarely has a perthitic texture; (6) plagioclase $\left(\mathrm{An}_{\left.\mathrm{s}_{-33}\right)}\right.$ ) is typically zoned (normal and oscillatory types; Plate 2i) in granodiorite and biotite monzogranite units, zoned and unzoned in leucomonzogranite units and unzoned ( $\mathrm{An}_{-\varsigma} ;$ Plate $\left.2 \mathrm{j}\right)$ in most leucogranite units; (7) andalusite (Plate 2k), with characteristic alteration to muscovite, is most abundant in fine-grained leucomonzogranite and leucogranite units; (8) subhedral to euhedral (primary magmatic?) topaz (Plate 21) is restricted to leucogranite rocks such as at East Kemptville where it may constitute up to $8 \%$ of the mode (Kontak, 1990; Ham and MacDonald, 1991).

In spite of these overall textural and mineralogical similarities throughout the batholith, several plutons display unique petrographic features. For example, minor amounts of metasomatic garnet (reaction relationship with biotite) are ubiquitous in both the fine- and coarse-grained leucomonzogranite rocks of the Big Indian Lake pluton (Fig. 4; Kontak and Corey, 1988) and rare to absent in the other twelve plutons. Similarly, trace amounts of secondary, metasomatic sillimanite (mostly fibrolite) are unique to the Big Indian Lake pluton (Corey, 1988b). Accessory titanite and epidote occur as inclusions, along with zircon, apatite, monazite and ilmenite, in biotite of the Davis Lake pluton and a cumulate phase in the Big Indian Lake pluton. Neither titanite nor epidote have been reported in any of the other eleven plutons. These mineralogical features suggest that different physiochemical conditions ( $\mathrm{T}, \mathrm{P}_{\mathrm{H} 2}, f \mathrm{O}_{2}$, bulk composition) prevailed in the various plutons.

\section{Geochemistry}

A total of 475 large (approximately $25 \mathrm{~kg}$ ), representative samples from the six main rock types were collected and analysed for major elements and a suite of 22 trace elements (Ba, Rb, Sr, Y, Zr, Nb, Pb, Zn, Cu, V, Ga, Hf, Ta, Sc, La, Th, $\mathrm{U}, \mathrm{As}, \mathrm{W}, \mathrm{Li}, \mathrm{F}$ and $\mathrm{Sn})$. Analytical data along with summaries of sample collection, preparation procedures and analytical methods are presented in Ham et al. $(1989,1990)$. Average major and trace element compositions and normative mineralogy, with standard deviations, for the six rock types are presented in Table 5 . The analytical errors are $\leq 2 \%$ for the major elements and $\leq 10 \%$ for most of the trace elements with the exception of $\mathrm{Pb}, \mathrm{Hf}, \mathrm{Ta}, \mathrm{La}, \mathrm{Th}$ and $\mathrm{U}$ where errors are $\leq 20 \%$ of the reported values.

Perhaps the most striking feature of the geochemistry of the batholith is the strong similarities in composition throughout the batholith. All rocks are peraluminous (i.e., molecular $\left.\mathrm{Al}_{2} \mathrm{O}_{3}\left(\mathrm{CaO}+\mathrm{K}_{2} \mathrm{O}+\mathrm{Na}_{2} \mathrm{O}\right)>1\right)$ and have relatively high $\mathrm{SiO}_{2}$ and low $\mathrm{CaO}$ with ranges from $67.12 \%$ (SD-1.73) and $1.94 \%$

Plate 1. Typical textures in the plutons of the South Mountain Batholith. (a) medium-to coarse-grained megacrystic; (b) medium- to coarse-grained seriate; (c) medium- to coarse-grained megacrystic with parallel alignment of feldspar megacrysts; (d,e) fine- and medium-grained equigranular; $(f, g)$ fine- to medium-grained and fine- to coarse-grained porphyritic; (h) coarse-grained pegmatitic. Abbreviations include: KF - alkali feldspar; PL - plagioclase; QZ - quartz. 
a $x^{2 / 2} \mathrm{KF}$

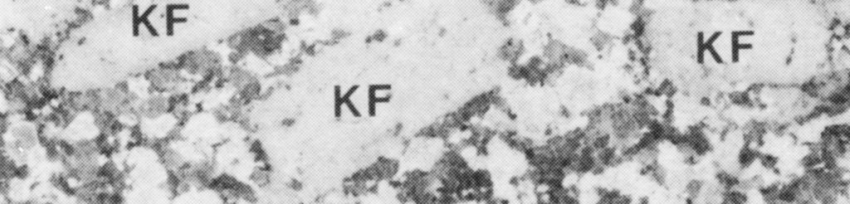

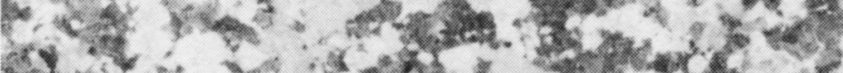

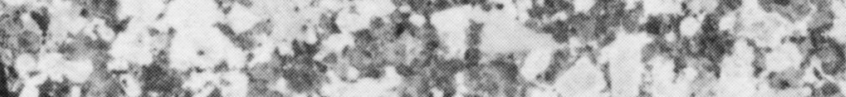

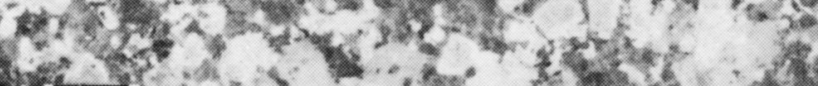

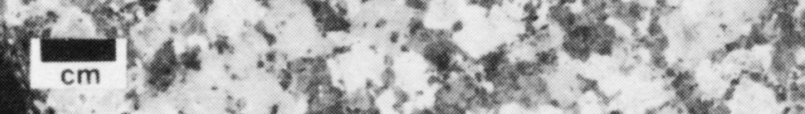

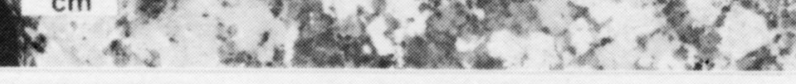

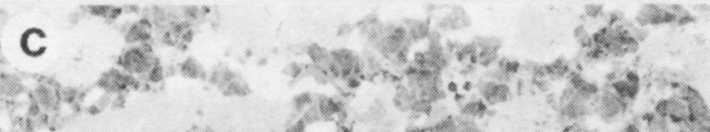

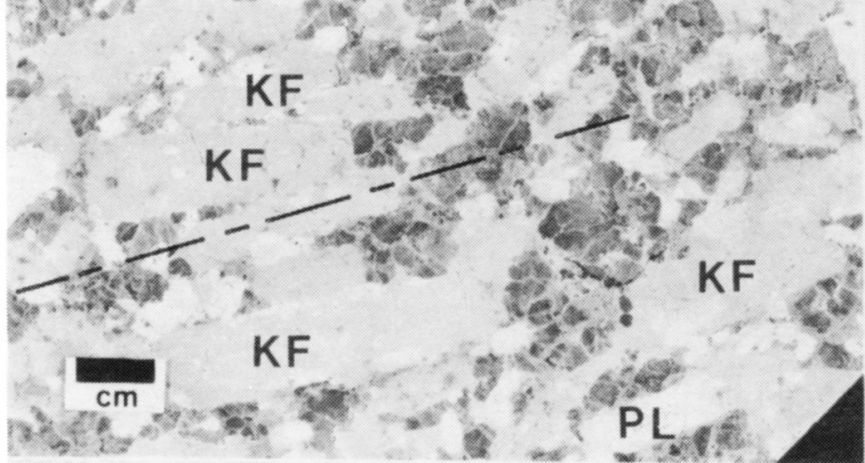

b thes

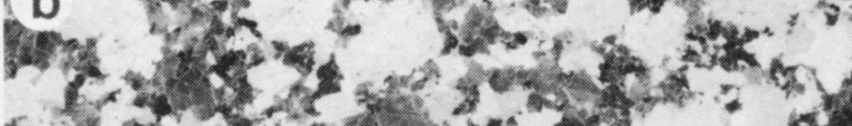

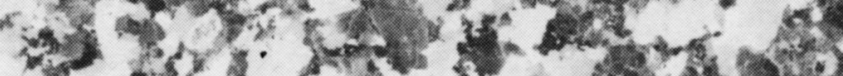
of 3 .

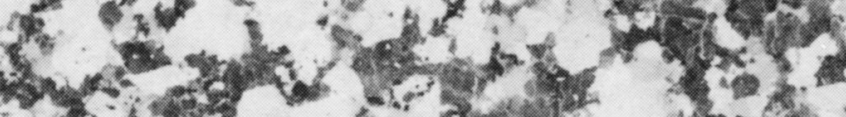

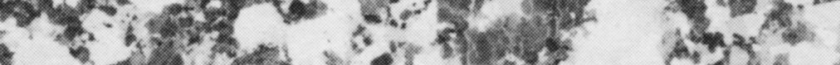

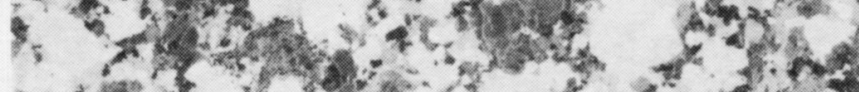
$\because \frac{c m}{*} x^{2}$

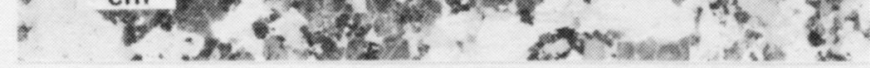

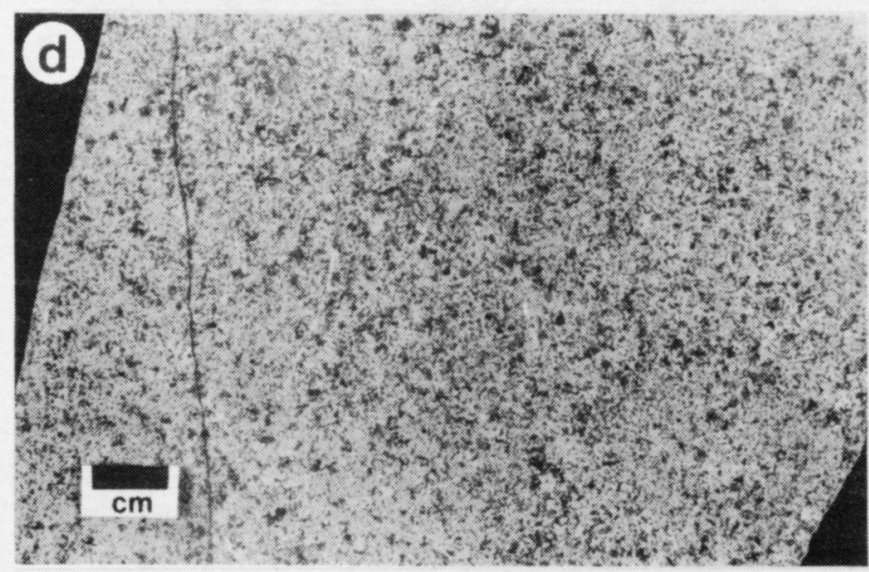

(e) $3 x+6 x^{2}+2 x^{2}+1$

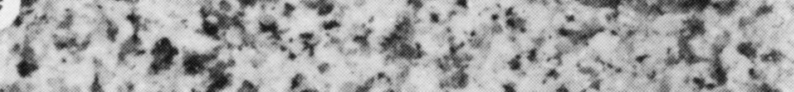

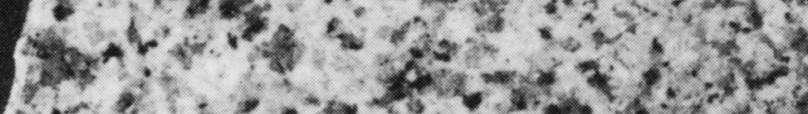
$x^{2}+2-x^{2}+x^{2}+25$ 2.

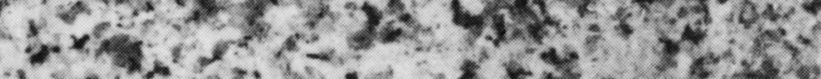
$4 x^{2}+5 x-2 x+2$ $x^{2}-x^{2} x^{2} x^{2}+x^{2}-2$

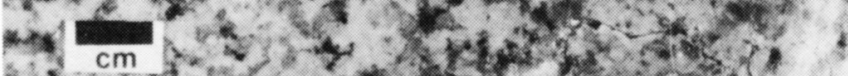

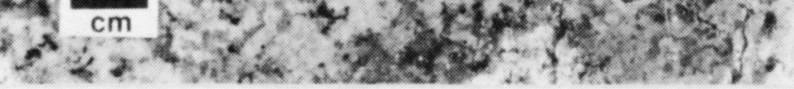

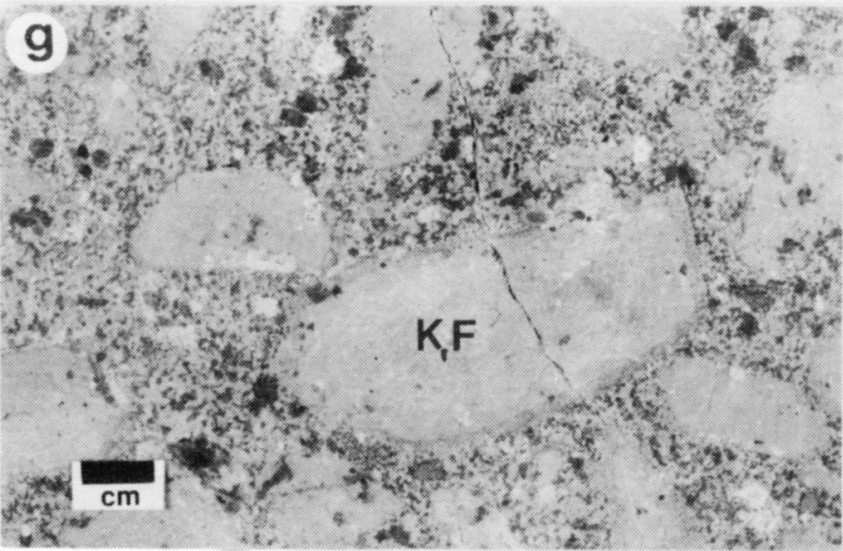

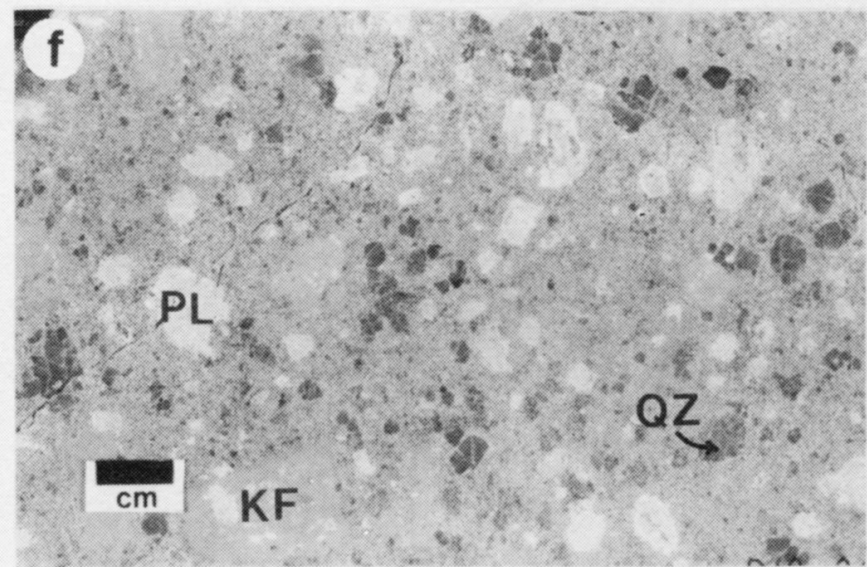

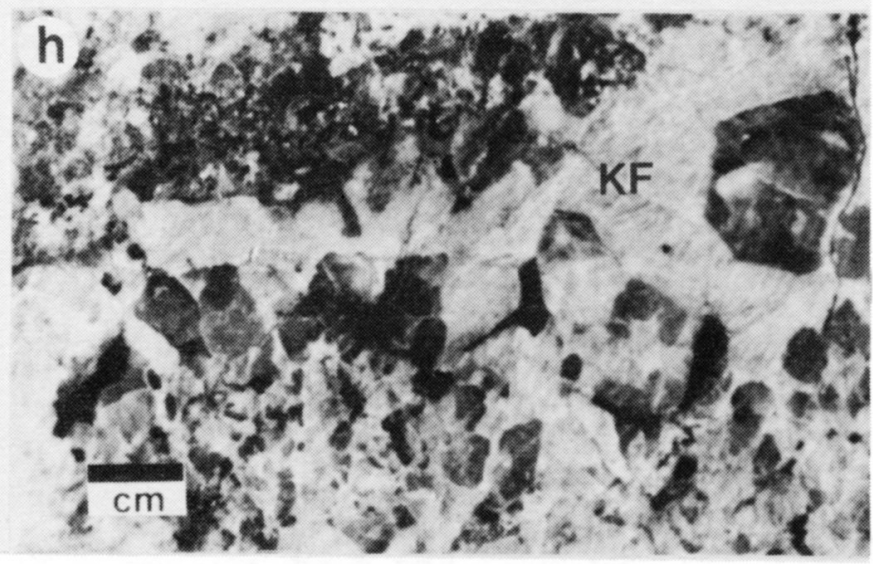




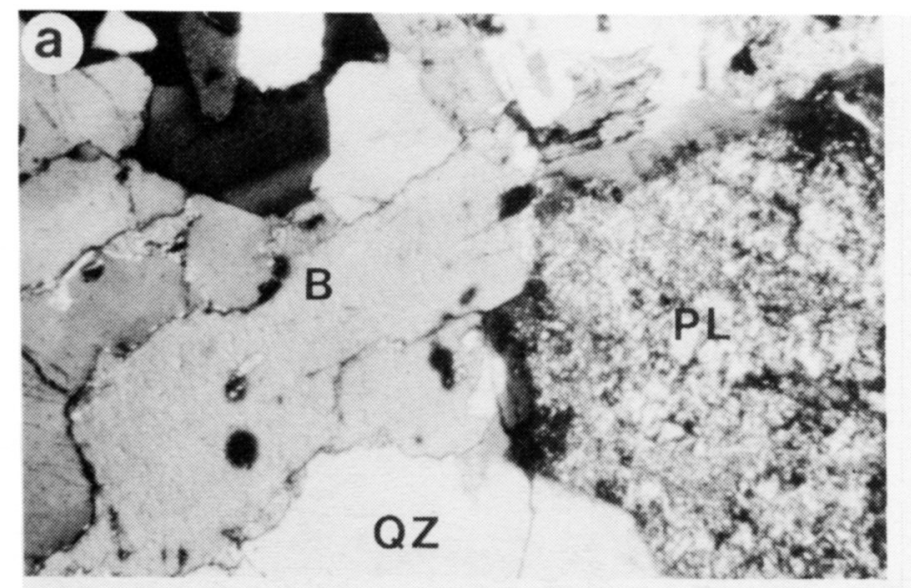

b
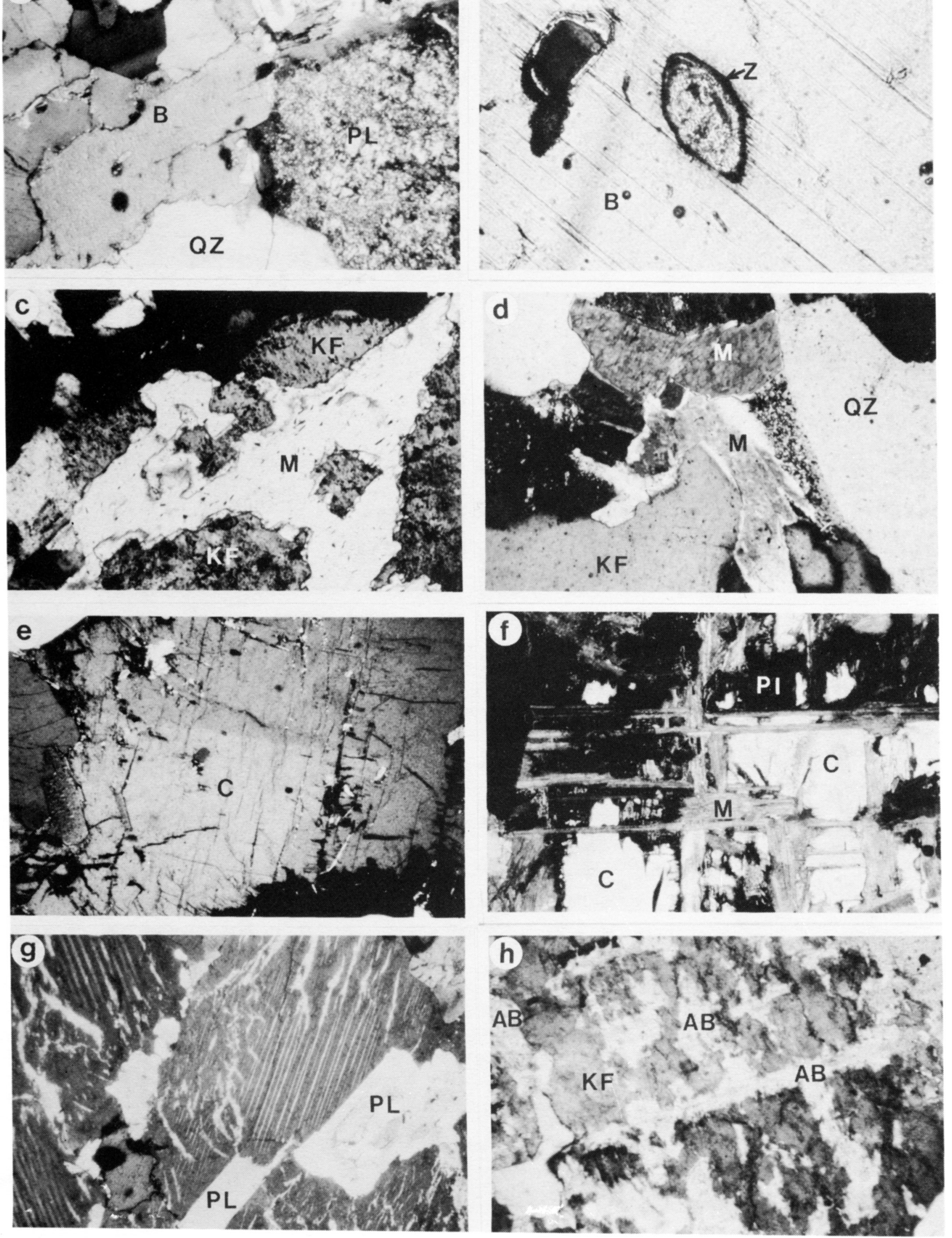

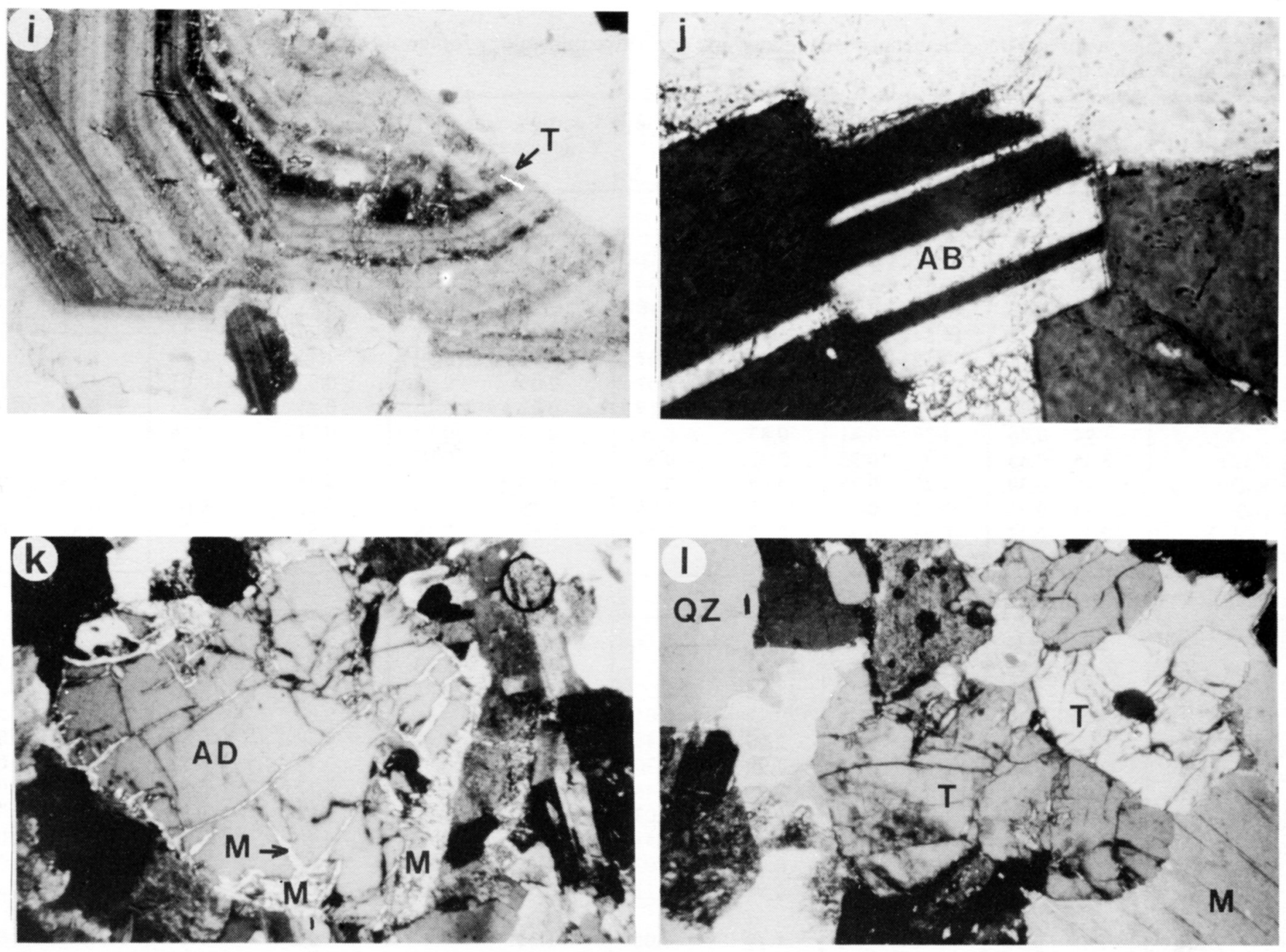

Plate 2. Photomicrographs illustrating typical mineralogical and textural feature of the plutons of the South Mountain Batholith. Length of photographs is $1 \mathrm{~mm}$ in all photos except $0.4 \mathrm{~mm}$ in b and j; all are in crossed polarized light. (a) biotite (B) with inclusions of zircon and/or monazite with pleochroic halos, sericitized plagioclase (PL) and quartz (QZ) in meg acrystic granodiorite; (b) zircon (Z) inclusion in biotite (B) in biotite monzogranite; (c) secondary muscovite (M) replacing alkali feldspar (KF) in coarse-grained leucomonzogranite; (d) euhedral to subhedral (primary?) muscovite (M) in leucogranite; (e) pristine cordierite crystal (C), showing prominent twin plane, in biotite monzogranite; (f) typical altered cordierite crystal (C) in coarse-grained leucomonzogranite with secondary muscovite developed along prominent crystallographic directions $(010)$ and pseudomorphic replacement by pinite (PI); (g) large alkali feldspar megacryst in biotite monzogranite displaying rod, bleb, flame and film perthitic exsolution and euhedral inclusions of plagioclase (PL); (h) alkali feldspar megacryst (KF) in coarse-grained leucomonzogranite with patch perthite exsolution of albite (AB); (i) plagioclase grain in biotite granodiorite displaying well developed oscillatory zoning and simple twin plane (T); (j) euhedral albite crystal (AB) in leucogranite; (k) andalusite grain (AD) with characteristic alteration to muscovite (M) in fine-grained leucomonzogranite; (1) cluster of topaz crystals $(\mathrm{T})$ and adjoining muscovite $(\mathrm{M})$ in leucogranite.

(SD-0.46), respectively, in granodiorite to $73.62 \%$ (SD-0.89) and 0.39 (SD-0.14), respectively, in leucogranite rocks. The major element chemistry and normative composition of the major rock types indicates a sequence from least evolved biotite granodiorite to most evolved leucogranite that reflects the petrographic features of the different rock types. This sequence is marked by systematic decreases in $\mathrm{TiO}_{2}, \mathrm{Fe}_{2} \mathrm{O}_{3}$, $\mathrm{MnO}, \mathrm{MgO}, \mathrm{CaO}, \mathrm{K} / \mathrm{Rb}$ and normative anorthite, enstatite, ilmenite, hematite, rutile and colour index and increases in $\mathrm{SiO}_{2}$, normative quartz, A/CNK and Thornton-Tuttle differentiation index. The concentration of $\mathrm{P}_{2} \mathrm{O}_{5}$ is generally consistent from granodiorite to fine-grained leucomonzogranite with a sudden increase in leucogranite units. This sequence is also marked by systematic decreases in several compatible trace elements (i.e., $\mathrm{Ba}, \mathrm{Sr}, \mathrm{Zr}, \mathrm{V}, \mathrm{Hf}, \mathrm{Sc}$ and $\mathrm{La}$ ) and increases in several incompatible trace elements (i.e., $\mathrm{Rb}, \mathrm{Ta}$, $\mathrm{U}, \mathrm{Li}, \mathrm{F}, \mathrm{Sn}$ and W). This overall systematic chemical behaviour is graphically displayed in Figure 6a-d. Pearson correlation coefficients $(n=475)$ have been included to illustrate the degree of correlation.

Despite the overall compositional similarities throughout the batholith, it is possible to distinguish among individual plutons. For example, binary element plots of $\mathrm{TiO}_{2}$ versus $\mathrm{Zr}$ and $\mathrm{Ta}$ versus $\mathrm{F}$ have been prepared for the Big Indian Lake and New Ross plutons. $\mathrm{TiO}_{2}$ and $\mathrm{Zr}$ are very strongly correlated in both plutons $(R=+0.98$ and +0.97 , respectively), 
Table 5. Average major and trace element concentrations and normative mineralogy for the six main rock types from the South Mountain Batholith (modified from Ham et al., 1990).

\begin{tabular}{|c|c|c|c|c|c|c|c|c|c|c|c|c|}
\hline $\begin{array}{l}\text { Rock } \\
\text { Type } \\
\#\end{array}$ & \multicolumn{2}{|c|}{$\begin{array}{l}\text { Biotite } \\
\text { Granodiorite } \\
65\end{array}$} & \multicolumn{2}{|c|}{$\begin{array}{l}\text { Biotite } \\
\text { Monzogranite } \\
\qquad 113\end{array}$} & \multicolumn{2}{|c|}{$\begin{array}{l}\text { Muscovite-Biotite } \\
\text { Monzogranite } \\
62\end{array}$} & \multicolumn{2}{|c|}{$\begin{array}{l}\text { Coarse-grained } \\
\text { Leucomonzogranite } \\
96\end{array}$} & \multicolumn{2}{|c|}{$\begin{array}{l}\text { Fine-grained } \\
\text { Leucomonzogranite } \\
\qquad 105\end{array}$} & \multicolumn{2}{|c|}{$\begin{array}{c}\text { Leucogranite } \\
34\end{array}$} \\
\hline \multicolumn{13}{|c|}{ MAJOR ELEMENTS } \\
\hline $\begin{array}{l}\mathrm{SiO}_{2} \\
\mathrm{TiO}_{2} \\
\mathrm{Al}_{2} \mathrm{O}_{3} \\
\mathrm{Fe}_{2} \mathrm{O}_{3} \\
\mathrm{MnO} \\
\mathrm{MgO} \\
\mathrm{CaO} \\
\mathrm{Na}_{2} \mathrm{O} \\
\mathrm{K}_{2} \mathrm{O} \\
\mathrm{P}_{2} \mathrm{O}_{5} \\
\mathrm{LOI}\end{array}$ & \begin{tabular}{r}
\multicolumn{1}{c}{$\mathrm{X}$} \\
67.12 \\
0.68 \\
15.46 \\
4.57 \\
0.09 \\
1.83 \\
1.94 \\
3.45 \\
3.70 \\
0.21 \\
0.65
\end{tabular} & $\begin{array}{l}\text { S.D. } \\
1.73 \\
0.13 \\
0.72 \\
0.81 \\
0.02 \\
0.24 \\
0.46 \\
0.45 \\
0.39 \\
0.03 \\
0.33\end{array}$ & $\begin{array}{r}\mathrm{X} \\
69.39 \\
0.49 \\
14.84 \\
3.62 \\
0.08 \\
1.48 \\
1.38 \\
3.36 \\
4.22 \\
0.20 \\
0.58\end{array}$ & $\begin{array}{l}\text { S.D. } \\
1.65 \\
0.13 \\
0.44 \\
0.79 \\
0.04 \\
0.26 \\
0.41 \\
0.33 \\
0.37 \\
0.03 \\
0.20\end{array}$ & $\begin{array}{r}\mathrm{X} \\
71.74 \\
0.32 \\
14.51 \\
2.45 \\
0.06 \\
1.16 \\
0.83 \\
3.43 \\
4.65 \\
0.23 \\
0.63\end{array}$ & $\begin{array}{l}\text { S.D. } \\
1.34 \\
0.10 \\
0.57 \\
0.57 \\
0.01 \\
0.19 \\
0.30 \\
0.37 \\
0.35 \\
0.05 \\
0.18\end{array}$ & $\begin{array}{c}X \\
73.07 \\
0.20 \\
14.25 \\
1.91 \\
0.05 \\
0.93 \\
0.64 \\
3.45 \\
4.64 \\
0.23 \\
0.54\end{array}$ & $\begin{array}{l}\text { S.D. } \\
1.43 \\
0.08 \\
0.69 \\
0.39 \\
0.01 \\
0.15 \\
0.32 \\
0.58 \\
0.48 \\
0.06 \\
0.18\end{array}$ & $\begin{array}{r}\mathrm{X} \\
73.90 \\
0.13 \\
14.26 \\
1.45 \\
0.05 \\
0.85 \\
0.41 \\
3.50 \\
4.48 \\
0.26 \\
0.64\end{array}$ & $\begin{array}{l}\text { S.D. } \\
1.18 \\
0.08 \\
0.47 \\
0.42 \\
0.01 \\
0.22 \\
0.18 \\
0.37 \\
0.34 \\
0.07 \\
0.21\end{array}$ & $\begin{array}{r}X \\
73.62 \\
0.07 \\
14.57 \\
1.34 \\
0.04 \\
0.76 \\
0.39 \\
3.69 \\
4.10 \\
0.41 \\
0.82\end{array}$ & $\begin{array}{l}\text { S.D. } \\
0.89 \\
0.04 \\
0.56 \\
0.53 \\
0.02 \\
0.10 \\
0.14 \\
0.70 \\
0.42 \\
0.16 \\
0.23\end{array}$ \\
\hline \multicolumn{13}{|c|}{ NORMATIVE MINERALOGY } \\
\hline $\begin{array}{l}\text { Quartz } \\
\text { Orthoclase } \\
\text { Albite } \\
\text { Anorthite } \\
\text { Corundum } \\
\text { Enstatite } \\
\text { Ilmenite } \\
\text { Hematite } \\
\text { Rutile } \\
\text { Apatite }\end{array}$ & $\begin{array}{r}\text { X } \\
26.89 \\
22.07 \\
29.44 \\
8.30 \\
2.80 \\
4.60 \\
0.19 \\
4.62 \\
0.58 \\
0.50\end{array}$ & $\begin{array}{l}\text { S.D. } \\
3.16 \\
2.34 \\
3.76 \\
2.27 \\
0.99 \\
0.61 \\
0.05 \\
0.83 \\
0.11 \\
0.08\end{array}$ & $\begin{array}{c}X \\
29.35 \\
25.22 \\
28.70 \\
5.57 \\
2.74 \\
3.71 \\
0.17 \\
3.65 \\
0.41 \\
0.47\end{array}$ & $\begin{array}{l}\text { S.D. } \\
2.97 \\
2.16 \\
2.75 \\
2.01 \\
0.65 \\
0.65 \\
0.03 \\
0.82 \\
0.13 \\
0.08\end{array}$ & $\begin{array}{c}\mathrm{X} \\
31.33 \\
27.66 \\
29.22 \\
2.60 \\
2.90 \\
2.90 \\
0.12 \\
2.47 \\
0.26 \\
0.54\end{array}$ & $\begin{array}{l}\text { S.D. } \\
2.74 \\
2.09 \\
3.04 \\
1.46 \\
0.70 \\
0.48 \\
0.03 \\
0.58 \\
0.09 \\
0.11\end{array}$ & $\begin{array}{c}\mathrm{X} \\
33.27 \\
27.64 \\
29.39 \\
1.71 \\
2.93 \\
2.34 \\
0.10 \\
1.93 \\
0.15 \\
0.53\end{array}$ & $\begin{array}{l}\text { S.D. } \\
3.33 \\
2.85 \\
4.94 \\
1.62 \\
0.82 \\
0.37 \\
0.02 \\
0.40 \\
0.08 \\
0.13\end{array}$ & $\begin{array}{r}\mathrm{X} \\
35.12 \\
26.68 \\
29.82 \\
0.52 \\
3.48 \\
2.12 \\
0.09 \\
1.46 \\
0.08 \\
0.61\end{array}$ & $\begin{array}{l}\text { S.D. } \\
2.85 \\
1.98 \\
3.11 \\
0.92 \\
0.72 \\
0.55 \\
0.03 \\
0.43 \\
0.08 \\
0.16\end{array}$ & $\begin{array}{c}\mathrm{X} \\
35.59 \\
24.44 \\
31.52 \\
0.02 \\
4.08 \\
1.92 \\
0.07 \\
1.33 \\
0.04 \\
0.97\end{array}$ & $\begin{array}{l}\text { S.D. } \\
3.97 \\
2.52 \\
5.97 \\
0.08 \\
0.88 \\
0.25 \\
0.02 \\
0.52 \\
0.04 \\
0.38\end{array}$ \\
\hline $\begin{array}{l}\text { A/CNK } \\
\text { TTDI } \\
\text { Col. Ind. }\end{array}$ & $\begin{array}{r}1.18 \\
78.41 \\
9.41\end{array}$ & $\begin{array}{l}0.10 \\
3.11 \\
1.35\end{array}$ & $\begin{array}{r}1.18 \\
83.27 \\
7.54\end{array}$ & $\begin{array}{l}0.06 \\
3.14 \\
1.33\end{array}$ & $\begin{array}{r}1.19 \\
88.21 \\
5.49\end{array}$ & $\begin{array}{l}0.06 \\
2.53 \\
1.00\end{array}$ & $\begin{array}{r}1.20 \\
90.31 \\
4.37\end{array}$ & $\begin{array}{l}0.07 \\
2.22 \\
0.69\end{array}$ & $\begin{array}{l}1.26 \\
1.62 \\
3.68\end{array}$ & $\begin{array}{l}0.07 \\
1.59 \\
0.85\end{array}$ & $\begin{array}{r}1.31 \\
91.55 \\
3.35\end{array}$ & $\begin{array}{l}0.15 \\
1.32 \\
0.6\end{array}$ \\
\hline \multicolumn{13}{|c|}{ TRACE ELEMENTS } \\
\hline $\begin{array}{l}\mathrm{Ba} \\
\mathrm{Rb} \\
\mathrm{Sr} \\
\mathrm{Zr} \\
\mathrm{Nb} \\
\mathrm{V} \\
\mathrm{Y} \\
\mathrm{Ga} \\
\mathrm{Cu} \\
\mathrm{Pb} \\
\mathrm{Zn} \\
\mathrm{Hf} \\
\mathrm{Ta} \\
\mathrm{Sc} \\
\mathrm{La} \\
\mathrm{Th} \\
\mathrm{U} \\
\mathrm{Li} \\
\mathrm{F} \\
\mathrm{As} \\
\mathrm{Sn} \\
\mathrm{W}\end{array}$ & $\begin{array}{c}X \\
667 \\
149 \\
168 \\
196 \\
12 \\
56 \\
32 \\
21 \\
7 \\
14 \\
78 \\
6 \\
1.2 \\
11.0 \\
36 \\
12.9 \\
3.0 \\
64 \\
666 \\
4.6 \\
5 \\
1\end{array}$ & $\begin{array}{c}\text { S.D. } \\
127 \\
28 \\
32 \\
38 \\
2 \\
14 \\
7 \\
3 \\
7 \\
9 \\
42 \\
1 \\
0.3 \\
2.2 \\
6 \\
1.6 \\
0.7 \\
26 \\
225 \\
7.1 \\
3 \\
1\end{array}$ & $\begin{array}{c}X \\
513 \\
179 \\
120 \\
165 \\
12 \\
37 \\
33 \\
19 \\
4 \\
17 \\
65 \\
5 \\
1.4 \\
8.5 \\
29 \\
11.6 \\
3.7 \\
75 \\
604 \\
4.5 \\
6 \\
1\end{array}$ & $\begin{array}{c}\text { S.D. } \\
128 \\
29 \\
26 \\
37 \\
2 \\
13 \\
6 \\
3 \\
6 \\
10 \\
15 \\
1 \\
1.2 \\
2.4 \\
6 \\
1.9 \\
1.1 \\
21 \\
119 \\
4.7 \\
4 \\
1\end{array}$ & $\begin{array}{c}X \\
348 \\
270 \\
76 \\
119 \\
13 \\
20 \\
26 \\
20 \\
3 \\
17 \\
57 \\
4 \\
1.9 \\
4.7 \\
23 \\
13.5 \\
5.8 \\
91 \\
924 \\
9.3 \\
9 \\
4\end{array}$ & $\begin{array}{c}\text { S.D. } \\
113 \\
76 \\
26 \\
23 \\
2 \\
11 \\
10 \\
3 \\
8 \\
13 \\
25 \\
1 \\
0.7 \\
1.5 \\
6 \\
4.1 \\
4.7 \\
29 \\
617 \\
44.1 \\
5 \\
13\end{array}$ & $\begin{array}{c}X \\
217 \\
310 \\
51 \\
89 \\
12 \\
9 \\
30 \\
19 \\
1 \\
11 \\
48 \\
3 \\
2.3 \\
3.1 \\
16 \\
11.3 \\
7.4 \\
106 \\
1105 \\
2.6 \\
15 \\
3\end{array}$ & $\begin{array}{c}\text { S.D. } \\
134 \\
114 \\
30 \\
32 \\
3 \\
7 \\
13 \\
3 \\
2 \\
11 \\
14 \\
1 \\
1.5 \\
1.1 \\
8 \\
4.6 \\
6.1 \\
74 \\
800 \\
2.3 \\
18 \\
3\end{array}$ & $\begin{array}{c}X \\
146 \\
343 \\
31 \\
59 \\
12 \\
4 \\
22 \\
21 \\
3 \\
19 \\
45 \\
2 \\
2.6 \\
3.1 \\
9 \\
6.3 \\
7.9 \\
108 \\
1002 \\
6.2 \\
18 \\
7\end{array}$ & $\begin{array}{c}\text { S.D. } \\
146 \\
123 \\
26 \\
27 \\
4 \\
6 \\
7 \\
3 \\
8 \\
8 \\
18 \\
1 \\
1.6 \\
1.0 \\
8 \\
4.2 \\
5.5 \\
76 \\
990 \\
8.4 \\
9 \\
13\end{array}$ & $\begin{array}{c}X \\
56 \\
641 \\
19 \\
39 \\
23 \\
2 \\
32 \\
27 \\
22 \\
16 \\
68 \\
1 \\
5.0 \\
2.5 \\
4 \\
5.3 \\
7.4 \\
236 \\
2550 \\
2.5 \\
23 \\
36\end{array}$ & $\begin{array}{c}\text { S.D. } \\
69 \\
257 \\
12 \\
15 \\
8 \\
3 \\
16 \\
5 \\
93 \\
26 \\
36 \\
1 \\
3.8 \\
1.0 \\
5 \\
4.0 \\
8.7 \\
155 \\
1372 \\
1.3 \\
13 \\
117\end{array}$ \\
\hline
\end{tabular}

Explanation: X - Arithmetic Mean; S.D. - Standard Deviation; $\mathrm{A} / \mathrm{CNK}$ - Molecular $\mathrm{Al}_{2} \mathrm{O}_{3} /\left(\mathrm{CaO}+\mathrm{Na}_{2} \mathrm{O}+\mathrm{K}_{2} \mathrm{O}\right)$; TTDI - Thorton-Tuttle Differentiation Index; Col. Ind. - Colour Index 
as would be expected from Figure $6 \mathrm{~b}$. However, the overall concentrations of these elements, and the slopes of regression lines, vary between the two plutons (Fig. 6e,f). The respective concentrations and distribution of $\mathrm{Ta}$ and $\mathrm{F}$ also vary between the two plutons, as displayed in Figure $6 \mathrm{~g}$,h.

Much of the chemical differences between individual plutons are more subtle that those shown in Figure 6 and are very difficult to recognize using conventional bivariate or ternary elemental plots. Horne et al. (1989) recognized chemical differences among biotite granodiorite and biotite monzogranite bodies from several stage 1 plutons using multivariate discriminant function analysis. They used a suite of high-field strength elements $\left(\mathrm{TiO}_{2}, \mathrm{Fe}_{2} \mathrm{O}_{3}, \mathrm{Zr}, \mathrm{Hf}\right.$ and $\left.\mathrm{Y}\right)$ and concluded that the compositional differences between the various plutons resulted from variations in the mineral chemistry of biotite and the varying proportions of the associated accessory minerals zircon and xenotime entrained within the biotite. It should be noted that while there was little overlap in discriminant function scores among the various stage 1 plutons, the within group variance generally exceeded the between group separation. Therefore, one of the main mathematical criteria for reliable discrimination was not satisfied. It is possible that chemical distinctions between the various plutons might be successfully recognized (i.e., satisfying all mathematical criteria) by using step-wise multiple discrimination as noted by Chatterjee and Strong (1984) in their study of metasomatized uraniferous rocks in the batholith. For the purpose of this correspondence, we have separated coarsegrained leucomonzogranite samples from six of the stage 2 plutons including Davis Lake, West Dalhousie, East Dalhousie, New Ross, Big Indian Lake and Halifax. We then applied the same multi-variate techniques and suite of elements as Horne et al. (1989) to determine if the stage 2 plutons could be discriminated. Preliminary results indicate that samples from four of the plutons (Davis Lake, West Dalhousie, Big Indian Lake, and Halifax) could be correctly assigned to their respective bodies with a 70 to $85 \%$ success rate, with the same mathematical restrictions as noted above. Conversely, the success rate for samples from the New Ross and East Dalhousie plutons was less convincing at only a $25 \%$ success rate. Samples from these plutons were often misclassified as belonging to the other pluton or, to a lesser extent, to one of the above plutons suggesting a possible genetic relationship between these two plutons.

\section{Role of Structure in the Evolution of the South Mountain Batholith}

Several previous workers have noted the presence of localized planar features within the batholith (McKenzie, 1974; Smitheringale, 1973). However, most previous studies have concluded that the South Mountain Batholith is a massive, post-tectonic body that was largely unaffected by regional deformation (Taylor, 1969; Cormier and Smith, 1973; Smith, 1974; McKenzie and Clarke, 1975). Several findings from our work indicate that structure played an important role in the evolution of the batholith.

(1) Most stage 1 plutons, particularly in the western portion of the batholith, display weak to moderately developed northeast-trending primary flow features (schlieren banding, feldspar megacryst-xenolith alignment, minor biotite foliation). These features parallel regional structural trends in the country rocks and have been interpreted as reflecting regional Acadian stress (Horne et al., 1988) during initial stages of magma emplacement. The northeast-trending elongate shape of several stage 1 plutons may reflect structural control during initial stages of emplacement. Conversely, their shape may reflect the exploitation of preexisting structures in the country rocks by the intruding stage 1 plutons. A full discussion of this issue is beyond the scope of this paper but is addressed by Horne et al., 1992.

(2) The East Dalhousie pluton and the southwestern extension of the Davis Lake pluton have narrow, northeasttrending, dyke-like shapes and are flanked by a series of faults and/or shear zones (Fig. 4). In several locales these stage 2 plutons have been variably deformed by movement along these faults. These observations prompted Horne $e t a l$. $(1988,1992)$ to suggest that the entire batholith was localized along a crustal scale structure. Results of a recent geochronological study of the East Kemptville-East Dalhousie fault zone, which partially forms the northern boundary of both plutons, indicates that these faults were episodically active from ca. 350 to $250 \mathrm{Ma}$ (Kontak et al., 1989; Kontak and Cormier, 1991). One explanation for the coincidence of faults and pluton boundaries is that some stage 2 plutons were emplaced along pre-existing structures that remained active for ca. $120 \mathrm{Ma}$ subsequent to emplacement of the plutons (Horne et al., 1992). Conversely, the stage 2 plutons may have initially intruded and subsequently been structurally modified to their present configuration by displacement along the observed faults. More structural data pertaining to the movement along the sundry faults of the batholith must first be collected before this issue can be resolved.

(3) Many of the fine-grained leucomonzogranite bodies within the stage 2 and, to a lesser extent stage 1, plutons have linear contacts that are crudely oriented to the northeast and northwest (Fig. 3). These orientations correspond to the major joint directions throughout the batholith and prompted Horne et al. (1988) to propose that the emplacement of these bodies was also structurally controlled. Finally, a detailed synthesis of the data for joints, dykes (i.e., aplite, pegmatite), quartz veins (mineralized and barren) and fracture/shear zones and faults from this study is presented in Horne $e t$ al. (1988). They concluded that these planar features developed during northwest, horizontal compression accompanying uplift during the waning stages of the Acadian Orogenic event.

The exact origin of some of the above structural features is somewhat contentious and requires additional study; however, our work suggests that the batholith was subjected to regional stresses commencing with the earliest emplacement of stage 1 plutons and continuing to the terminal stages during which time mineralization occurred. These regional stresses probably relate to the waning stages of the Acadian Orogeny and also are manifest as transpressional displacement along the Cobequid Chedabucto fault zone (Fig. 1). 


\section{Time OF EMPLACEMENT}

Numerous geochronological studies of the batholith have been undertaken during the past two decades. Reynolds $e t a l$. $(1981,1987)$ concluded, on the basis of $\mathrm{K} / \mathrm{Ar}$ and ${ }^{40} \mathrm{Ar} /{ }^{39} \mathrm{Ar}$ age determinations (biotite and muscovite), that the bulk of the granodiorite, monzogranite and leucomonzogranite of the batholith were emplaced ca. $370 \mathrm{Ma}$. Using the $\mathrm{Rb} / \mathrm{Sr}$ method, Clarke and Halliday (1980) concluded that there was an age difference of $10 \mathrm{Ma}$ between the granodiorite (ca. 370 $\mathrm{Ma}$ ) and late-stage leucomonzogranite porphyries (ca. 360 $\mathrm{Ma}$ ) of the central part of the batholith. However, U/ $\mathrm{Pb}$ dates for monazite separated from the same sample suite (Harper, 1988) revealed uniform ca. $370 \mathrm{Ma}$ ages. $\mathrm{An}{ }^{40} \mathrm{Ar} /{ }^{39} \mathrm{Ar}$ study of a suite of muscovites from twelve leucogranite and finegrained leucomonzogranite bodies of the eastern half of the batholith yielded uniform plateau ages of $372 \pm 3 \mathrm{Ma}$ (Clarke et al., 1990).

Richardson et al. (1989) interpreted a five point $\mathrm{Rb} / \mathrm{Sr}$ isochron age of $330 \pm 7 \mathrm{Ma}$ to represent the time of intrusion and crystallization of the Davis Lake pluton, although three previously published ${ }^{40} \mathrm{Ar} /{ }^{39} \mathrm{Ar}$ mica dates of ca. $370 \mathrm{Ma}$ (Reynolds et al., 1981) suggested otherwise. An overwhelming amount of data has recently been published that contradicts the conclusions of Richardson et al. (1989). For example, Kontak and Cormier (1991) and Kontak et al. (1989) conducted $\mathrm{Rb} / \mathrm{Sr}$ dating in the East Kemptville area of the Davis Lake pluton and concluded that the "younger" Carboniferous ages reflect resetting due to episodic tectonic activity along localized shear zones. Chatterjee and Cormier (1991) reported a 27 point whole rock $\mathrm{Rb} / \mathrm{Sr}$ isochron age of $375 \pm 3$ (MSWD $=1.88 ;{ }^{87} \mathrm{Sr} /{ }^{86} \mathrm{Sr}=0.7054 \pm .0023$ ) for samples from the Davis Lake pluton. Finally, recent $\mathrm{Pb} / \mathrm{Pb}$ studies of the western part of the batholith (Chatterjee and Ham, 1991) including the Davis Lake pluton (Chatterjee and MacDonald, 1991; Kontak and Chatterjee, in press), support a ca. $370 \mathrm{Ma}$ age for intrusion and crystallization.

In short, there is ample evidence suggesting that all thirteen plutons of the South Mountain Batholith intruded and crystallized within a very narrow time interval, say $\leq 5$ Ma at ca. $370 \mathrm{Ma}$. The concordancy of all the radiometric dating techniques which collectively have a large range in terms of blocking temperatures (i.e., near the solidus to ca. $250^{\circ} \mathrm{C}$ ) implies rapid post-crystallization cooling. Younger dates within the batholith reflect variable degrees of updating during subsequent thermal and tectonic disturbances. De- spite the restricted time of emplacement, a systematic sequence of emplacement is evident throughout. Firstly, stage 1 plutons were emplaced. Exposed contacts between these plutons are rare, however, where observed, chilled margins and other definitive contact relations are generally absent. Subsequent to this stage 2 plutons were emplaced and several contacts with stage 1 plutons have been observed. With the exception of a gradational contact at the margin of the Halifax pluton, all stage 1 and 2 contacts appear to be intrusive in nature. None of the stage 2 plutons have chilled margins, with the exception of a narrow zone $(<200 \mathrm{~m})$ along the northern contact of the East Dalhousie pluton and surrounding country rocks. The coarse-grained megacrystic units of the stage 2 plutons were the first to crystallize. Contacts between these units were noted to be both intrusive and gradational. The emplacement of the fine-grained leucomonzogranite and leucogranite bodies appear to represent the final magmatic event, with the exception of a few fine-grained leucomonzogranite bodies that are in gradational contact with host megacrystic rocks (textural equivalents). The paucity of chilled margins indicates contemporaneous cooling of the various plutons, thus supporting the geochronological data. This factor, coupled with the lack of definitive contact relations at the major pluton boundaries, inhibits any further refinement of the overall emplacement history for the thirteen plutons.

\section{Metallogeny of the South Mountain BathOLITH}

As stated in the introduction, the South Mountain Batholith is host to numerous polymetallic mineral deposits and occurrences. Most workers have concluded that this mineralization resulted from the deposition by late- to post-magmatic hydrothermal fluids (Charest, 1976; O'Reilly et al., 1982; Chatterjee et al., 1985; Logothetis, 1985; Richardson, 1988; Kontak, 1990). These conclusions are largely based on: (1) the common spatial association with late-stage leucocratic rocks (e.g., the East Kemptville Sn and Millet Brook U deposits); (2) the ubiquitous presence and style of hydrothermal alteration, including albitization, $\mathrm{K}$-feldspathization, muscovitization, silicification and rare desilicification (episyenitization); and (3) the "granophile" character of the associated elemental suite which corresponds to the SWUMtype ( $\mathrm{S} n \pm \mathrm{W} \pm \mathrm{U} \pm \mathrm{Mo}$ ) association of Strong (1981).

Smith and Turek (1976) evaluated the economic poten-

Fig. 6. Chemical variation in the plutons of the South Mountain Batholith. Pearson correlation coefficients ( $R$ ) are presented for all bivariate plots. Abbreviations for rock types in 6a-d are same as in Figure 5. Shaded arrows indicate overall compositional trends from biotite granodiorite to leucogranite. Symbols used in 6e-h include: $(+)$ muscovite-biotite monzogranite; $(x)$ coarse-grained leucomonzogranite; $(A)$ fine-grained leucomonzogranite; and $(\square)$ leucogranite. Figure 6a-d display the overall similarities of the main rock types throughout the batholith and the progressive decrease in colour index, $\mathrm{TiO}_{2}, \mathrm{Zr}$ and $\mathrm{Sr}$, and concomitant increase in Thornton-Tuttle differentiation index (TTDI), Rb, Ta and $\mathrm{F}$ from granodiorite to leucogranite. Average values for each rock type have been plotted. Bars correspond to the standard deviation. The deflections in trends between FGLMG and LG $(a, c)$ and the increased standard deviations for $\mathrm{Rb}, \mathrm{Ta}$ and $\mathrm{F}$ in LG (c,d) reflect increased involvement of volatile-rich fluid phase (Kontak et al., 1988; MacDonald and Clarke, 1991). Bivariate plots of $\mathrm{Zr}-\mathrm{TiO}_{2}$ and $\mathrm{F}-\mathrm{Ta}$ for the $\mathrm{Big}$ Indian and New Ross plutons (BIP and NRP) are given in $6 \mathrm{e}-\mathrm{f}$. In spite of similar $\mathrm{R}$ values for $\mathrm{Zr}-\mathrm{TiO}_{2}$ in the two plutons, the actual concentrations in the different rock types and the slopes of the regression lines are somewhat different. A much more pronounced difference is displayed in the F-Ta plot ( $\mathrm{g}, \mathrm{h})$. 

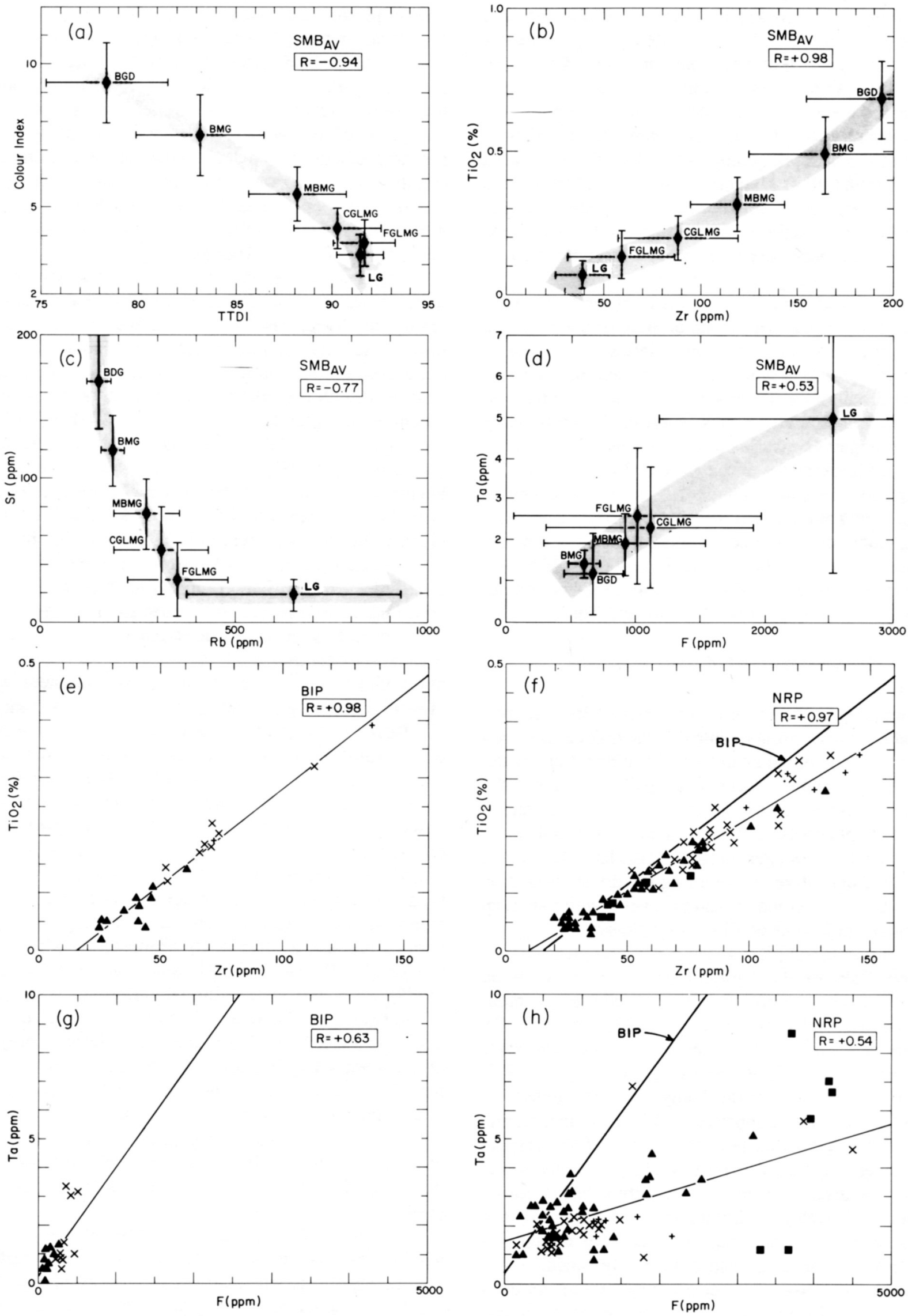
tial of three composite plutons (mostly stage 2 plutons with some adjoining stage 1 rocks) using petrological indices and geochemical parameters. They concluded that the three examined plutons had differing economic potential. Chatterjee (1983) proposed a series of metallogenic domains within the batholith based upon the styles and elemental assemblages of all mineral occurrences. The domains were established independently of the bedrock geology of McKenzie and Clarke (1975) and Smith (1974). Numerous "new" occurrences have subsequently been found, both during our mapping and from mineral exploration activities. The elemental associations and styles of these occurrences are consistent with the previously proposed metallogenic domains.

Our recent work indicates that many of the domains of Chatterjee (1983) occur within one or more of the proposed plutons. In fact, several domain boundaries correspond to margins of our proposed plutons. This suggests that individual plutons are directly responsible for their respective deposit types and associated suites of elements, presumably through prolonged crystal fractionation. The differences in the polymetallic character of the various domains probably reflect variations in bulk composition and physio-chemical conditions during emplacement/crystallization, and possibly varying amounts of crustal contamination during emplacement, within the various plutons of the batholith. If so, the economic mineral potential of each pluton should be considered individually, as suggested by Smith and Turek (1976).

\section{Summary and Discussion}

Our mapping of the batholith has defined 260 intrusive bodies that have been grouped into 49 map units based upon similar texture, composition and field relations. Further detailed mineralogical and geochemical studies resulted in the delineation of thirteen plutons. It should be stressed that the recognition of pluton boundaries is somewhat problematic because of similarity of ages throughout the batholith, a lack of chilling and definitive cross-cutting relationships at most major granite/granite contacts, and the overall mineralogical and chemical similarities of all granitic phases.

Prior to our survey, it was generally accepted that approximately $75 \%$ of the batholith was comprised of an "envelope" of granodiorite that hosted later-stage monzogranite bodies (McKenzie and Clarke, 1975; Smith, 1979). Although previous mapping resulted in only a few local-scale divisions of the "envelope" rocks (Smitheringale, 1973; McKenzie, 1974), results of this study demonstrate that this "envelope" is, in fact, comprised of biotite monzogranite with subordinate granodiorite $(52.2 \%$ versus $9.6 \%$, respectively). Perhaps more significantly, we have established the presence of five discrete stage 1 plutons within the previously homogeneous "envelope". Extensive point counting and geochemical investigations indicates that four of the five stage 2 plutons are normally and/or reversely zoned.

Our work has defined a systematic sequence of emplacement beginning with the intrusion of the stage 1 plutons which was followed by a series of eight monzogranite leucomonzogranite - leucogranite stage 2 plutons. Contacts between the stage 1 and 2 plutons are intrusive except for the Halifax pluton where a gradational contact is developed (Fig. 4) with surrounding biotite monzogranite (separate pluton?). The coarse-grained, often megacrystic units of the stage 2 plutons crystallized first. The contacts between these map units were observed to be both intrusive and gradational. The fine-grained leucomonzogranite and leucogranite units were the last rocks to be emplaced in the batholith. Contacts with country rocks were predominantly intrusive with the exception of a few bodies, mostly in the New Ross pluton, where gradational contacts indicate they are textural equivalents of the host rocks (Corey, 1988a).

Detailed petrographic studies of the six main rock types indicate that rocks of the various plutons have similar mineralogical characteristics. For example, the presence of biotite, muscovite, aluminosilicate (e.g., andalusite), cordierite, garnet and tourmaline, in virtually all of the plutons, is consistent with the "characteristic" mineral assemblage for peraluminous granites as defined by Clarke (1981). This same mineral assemblage, in particular the abundance of cordierite (up to 5\%), combined with the absence of hornblende and titanite is consistent with "S-type" granitoids as described by Chappell and White (1974) and White et al. (1986). The only occurrence of magnetite in the entire batholith is in a single sample of albite-magnetite breccia from a drill hole near the East Kemptville deposit (Richardson, 1988) where the presence of intense alteration and deformation suggests a post-magmatic origin for the assemblage. The ubiquitous occurrence of accessory ilmenite, along with muscovite and low $\mathrm{Mg} / \mathrm{Fe}$ biotite, is consistent with the "ilmenite-series" granitoids as described by Ishihara (1977).

Detailed chemical studies demonstrate that the rocks of the batholith have similar overall chemical characteristics with $\mathrm{A} / \mathrm{CNK}>1$, high levels of $\mathrm{SiO}_{2}$ and low levels of $\mathrm{CaO}$. Major and trace element chemistry and normative compositions define a continuous sequence from least-evolved granodiorite to most-evolved leucogranite. This sequence is interpreted as representing fractional crystallization with the progressive removal of plagioclase, $\mathrm{K}$-feldspar and inclusion-rich biotite (zircon, monazite, apatite, ilmenite) in the various plutons, as previously proposed by McKenzie and Clarke (1975), Smith (1979) and MacDonald and Horne (1988), to explain compositional variations within portions of the batholith. The recent discovery of a plagioclase-rich cumulate phase in the Big Indian Lake pluton (Corey, 1992) also supports the fractional crystallization model for the batholith. Deflections in chemical trends (Fig. 6a,c,d), and drastic increases in standard deviations for several "incompatible" trace elements in leucogranitic units are interpreted as reflecting fluid/melt and/or fluid/rock processes as suggested by Kontak et al. (1988) and MacDonald and Clarke (1991).

In spite of the overall compositional similarities, our work has documented slight, but significant, variations in the mineralogy and geochemistry of the various plutons. In fact, similar rock units (e.g., biotite monzogranite, coarse-grained leucomonzogranite) from different plutons have successfully been discriminated using multi-variate statistical techniques 
(Horne et al., 1989; our unpublished data). One explanation for these compositional variations is that varying physiochemical conditions prevailed during crystallization of the sundry plutons. However, the suite of elements used in the multi-variate discriminate function analysis was entirely highfield strength elements that reside primarily in biotite and its inclusions. MacDonald and Clarke (1991) have established that these elements are the least effected by late- and postmagmatic processes, that is, the processes that would be most likely to vary with changing physio-chemical conditions. In fact, the distribution of these elements is strongly controlled by the bulk composition of the melt and the respective distribution coefficients. Therefore, the authors favour an alternate explanation in which the slight compositional differences are manifestations of chemical heterogeneities in the protoliths that were melted to form the thirteen plutons. Based upon physical constraints for the emplacement of magmas in the batholith, Horne et al. (1992) conclude that the various plutons were generated by melting of crustal rocks approximately beneath their present location. Therefore, it is reasonable to expect regional changes in protolith composition.

Three opposing models for the origin and emplacement of the South Mountain Batholith have been advanced. Firstly, McKenzie and Clarke (1975), Charest et al. (1985) and Clarke and Muecke (1985) have proposed that the entire batholith represents a single co-magmatic body that fractionated in situ (?). Conversely, Smith and Turek (1976) and Smith (1979) suggested that batholith was emplaced as a series of discrete plutons that subsequently coalesced to form a composite batholith. In both instances, the entire batholith was assumed to have crystallized ca. 360 to $370 \mathrm{Ma}$. Lastly, Richardson et al. (1989) concluded that the Davis Lake pluton was intruded approximately 30 to $40 \mathrm{Ma}$ after the main "cogenetic" South Mountain Batholith. They concluded that the Davis Lake pluton was generated by remelting of the residue from the first melting event that generated the rest of the batholith. Our work has substantially refined the original geological map of the batholith and has enabled us to shed new insight into its intrusion and crystallization history.

There is overwhelming geochronological evidence that the entire batholith was emplaced during a very narrow time interval at ca. $370 \mathrm{Ma}$, as discussed above, despite the definitive emplacement sequence observed during our mapping. This restricted time interval for emplacement of the batholith predicates the generation of massive amounts of granitic magma pre-370 Ma. As discussed above, recent detailed petrographic, geochemical and isotopic studies of xenoliths from a mafic dyke near Tangier (Eberz et al., 1988, 1991) indicate that upper crustal rocks, possibly from the Avalon Terrane, were subducted beneath the Meguma Terrane during the continent/continent collision related to the Acadian Orogeny. The subjection of upper crustal rocks to lower crustal P-T conditions would necessitate melting and the generation of peraluminous, felsic magma. In addition, the presence of ca. $370 \mathrm{Ma}$ mantle-derived mafic intrusions in the Liscomb complex (Chatterjee and Giles, 1988; Kontak et al., 1990) suggests that underplating of the Tangier-Liscomb area by mantle magma also occurred. Therefore, the massive amounts of granitic magma required to form the composite South Mountain Batholith may be explained by similar processes evoked (Eberz et al., 1991; Clarke et al., in press) to explain the genesis of the Tangier granulite xenoliths, the Liscomb gneisses and the nearby granites.

\section{Conclusions}

Several important conclusions can be drawn from our recent detailed mapping project:

(1) The South Mountain Batholith comprises thirteen separate plutons that can be separated into early biotitebearing monzogranite and granodiorite stage 1 plutons and late muscovite \pm biotite monzogranite - leucomonzogranite - leucogranite stage 2 plutons.

(2) The emplacement of these plutons, the late-stage finegrained leucomonzogranite bodies and post-magmatic veins and fracture zones (barren and mineralized) were partially controlled by residual stresses related to the waning stages of the Acadian Orogeny.

(3) Evaluation of published geochronological data indicates that all plutons were emplaced ca. $370 \mathrm{Ma}$.

(4) Select mineralogical and geochemical data suggest that the various plutons were generated by melting of various protoliths with differing compositions, thus generally supporting the models of Smith and Turek (1976) and Smith (1979).

(5) The observed metallogenic domains of Chatterjee (1983) crudely correspond to individual or groups of plutons and reflect chemical diversity within the zone of partial melting.

\section{Acknowledgements}

The authors would like to express their gratitude to A.K. Chatterjee for proposing the South Mountain Batholith project and for his insightful discussions pertaining to the various aspects of granite petrogenesis. Dan Kontak is gratefully acknowledged for helpful discussions, motivating us to write this paper and critically reviewing an earlier version of the manuscript. Our colleagues Philip Finck, Mark Graves and Fred Boner are thanked for their many discussions of the relationship between the various till sheets and underlying bedrock geology of southwestern Nova Scotia. George O'Reilly, Paul Smith and Peter Giles are also acknowledged for their stimulating discussions on the structural and economic geology of the South Mountain Batholith and surrounding country rocks. We appreciate the contributions of Joe Campbell and other staff of the drafting section who prepared all of the figures. Barb MacDonald prepared the tables. We wish to acknowledge the helpful comments offered by two reviewers, A. Clark and A.E. LaLonde. This paper is published with the permission of the Director of the Mineral Resources Division of the Nova Scotia Department of Natural Resources. 
Bateman, P.C. 1988. Constitution and genesis of the Central Part of the Sierra Nevada Batholith, California. United States Geological Survey Open File Report 88-382, 188 p.

Bell, K. and Blenkinsop, J. 1960. Mississippian Horton Group of type Windsor-Horton district, Nova Scotia. Geological Survey of Canada, Memoir 314, 112 p.

Cha PPELL, B.W. and White, A.J.R. 1974. Two contrasting granite types. Pacific Geology, 8, pp. 173-174.

Charest, M.H. 1976. Petrology, geochemistry and mineralization of the New Ross area, Lunenburg County, Nova Scotia. Unpublished M.Sc. thesis, Dalhousie University, Halifax, Nova Scotia, 154 p.

Charest, M.H., Farley, E.J., and Clarke, D.B. 1985. The northwestern part of the New Ross-Vaughan Complex: petrology, geochemistry and mineral deposits. In Guide to the Granites and Mineral Deposits of Southwestern Nova Scotia. Edited by A.K. Chatterjee and D.B. Clarke. Nova Scotia Department of Mines and Energy, Paper 85-3, pp. 29-40.

Chatterjee, A.K. 1983. Metallogenic map of Nova Scotia. Nova Scotia Department of Mines and Energy map, scale 1:500,000.

Chatterjee, A.K. and Cormier, R.F. 1991. A Rb/Sr geochronological study of the Davis Lake pluton, South Mountain Batholith, southern Nova Scotia: Evidence for $375 \mathrm{Ma}$ time of emplacement. Nova Scotia Department of Mines and Energy, Report 91-5.

Chatterjee, A.K. and Giles, P.S. 1988. Meguma Zone basement II: P-T evolution of granulite xenoliths. Annual Meeting, Geological Association of Canada, Program with Abstracts, 13 , p. A19.

Chatterjee, A.K. and HaM, L.J. 1991. U-Th-Pb systematics of the South Mountain Batholith, Nova Scotia. In Program with Abstracts, Atlantic Geoscience Society Annual Colloquium, Amherst, Nova Scotia, February 1991.

Chatterjee, A.K. and MacDonald, M.A. 1991. Contrasting greisens and associated granitoid rocks of the Davis Lake pluton: Implications for the origin of the East Kemptville tin deposit, Nova Scotia. In Proceedings with Abstracts, Atlantic Geoscience Society Annual Colloquium, Amherst, Nova Scotia, February 1991.

Chatterjee, A.K. and Strong, D.F. 1984. Discriminant and factor analysis of geochemical data from granitoid rocks hosting the Millet Brook uranium mineralization, South Mountain Batholith, Nova Scotia. Uranium, 1, pp. 289-305.

Chatterjee, A.K., Strong, D.F., Clarke, D.B., Robertson, J., Pollock, D., and Murcke, G.K. 1985. Geochemistry of the granodiorite hosting uranium mineralization at Millet Brook. In Guide to the Granites and Mineral Deposits of Southwestern Nova Scotia. Edited by A.K. Chatterjee and D.B. Clarke. Nova Scotia Department of Mines and Energy. Paper 85-3, pp. 63-114.

Clarke, D.B. 1981. The mineralogy of peraluminous granites: a review. Canadian Mineralogist, 19, pp. 3-17.

Clarke, D.B. and Chatterjee, A.K. 1988. Physical and chemical processes in the South Mountain Batholith. In Recent advances in the geology of granite-related mineral deposits. Edited by R.P. Taylor and D.F. Strong. Canadian Institute of Mining and Metallurgy, Special Volume 39, pp. 223-233.

CLARKE, D.B. and HALlidaY, A.N. 1980. Strontium isotope geology of the South Mountain Batholith, Nova Scotia. Geochimica et Cosmochimica Acta, 44, pp. 1045-1058.

Clarke, D.B. and Muecke, G.K. 1985. Review of the petrochemistry and origin of the South Mountain Batholith and associ- ated plutons, Nova Scotia, Canada. In High Heat Production (HHP) Granites, Hydrothermal Circulation and Ore Genesis. Institution of Mining and Metallurgy, England, pp. 41-54.

Clarke, D.B., Reynolds, P.H., MacDonald, M.A., and LonoSTAFFE, F.J. 1990. Origins of two leucogranite types from the eastern part of the South Mountain Batholith, Nova Scotia. Geological Society of America Annual Meeting, Program with Abstracts, p. A243.

Clarke, D.B., Chatterjee, A.K., and Giles, P.S. In press. The Liscomb Complex: A microcosm of peraluminous granite production for the Meguma Zone of Nova Scotia. Contributions to Mineralogy and Petrology.

Cobbing, E.J., Pitcher, W.S., Wilson, J.J., Baldock, J.W., TAYLoR, W.P., McCourT, W., and SNelling, N.J. 1981. The geology of the western Cordillera of northern Peru. Institute of Geological Sciences, Overseas Memoir 5, 143 p.

Corey, M.C. 1987. Bedrock geological map of Mount Uniacke, NTS sheet $11 \mathrm{D} / 13$ (west half). Nova Scotia Department of Mines and Energy, Map 87-8, scale 1:50,000.

1988a. Preliminary geological map of Chester, NTS sheet 21A/09. Nova Scotia Department of Mines and Energy, Open File Map 88-013, scale 1:50,000.

- 1988b. An occurrence of metasomatic aluminosilicates related to high alumina hydrothermal alteration within the South Mountain Batholith, Nova Scotia. Maritime Sediments and Atlantic Geology, 24, pp. 83-95.

- 1992. Geological features within the Big Indian Lake pluton, Hants County, Nova Scotia: evidence of igneous layering from recent diamond drilling. Atlantic Geology, 28, pp. 51-62.

Corey, M.C. and Horne, R.J. 1989a. Preliminary geological map of Lake Rossignol, NTS sheet 21A/03. Nova Scotia Department of Mines and Energy, Open File Map 89-010, scale $1: 50,000$.

1989b. Preliminary geological map of Milford, NTS sheet 21A/11. Nova Scotia Department of Mines and Energy, Open File Map 89-014, scale 1:50,000.

Cormier, R.F. and SMITH, T.E. 1973. Radiometric ages of granitic rocks, southwestern Nova Scotia. Canadian Journal of Earth Sciences, 10, pp. 1201-1210.

Eberz, G.W., Clarke, D.B., Chatterjee, A.K., and Giles, P.S. 1988. Meguma Zone basement III: geochemistry of lower crustal xenoliths. Geological Association of Canada Annual Meeting. Program with Abstracts, 13:A35.

1991. Chemical and isotopic composition of the lower crust beneath the Meguma lithotectonic zone, Nova Scotia: evidence from granulite facies xenoliths. Contributions to Mineralogy and Petrology, 109, pp. 69-88.

Fairbairn, H.W., Hurley, P.M., and Pinsen, W.H. 1964. Preliminary age study and initial $\mathrm{Sr}^{87} / \mathrm{Sr}^{86}$ of Nova Scotia granitic rocks by the Rb-Sr whole rock method. Geological Society of America Bulletin, 75, pp. 253-258.

Fairbault, E.R. 1908. City of Halifax sheet, Map No. 68. Geological Survey of Canada, Publication No. 1019.

1924. Chester Basin. Geological Survey of Canada, Map 87.

Giles, P.S. 1985. A major post-Visean sinistral shear zone - new perspectives on Devonian and Carboniferous rocks of southern Nova Scotia. In Guide to the granites and mineral deposits of southwestern Nova Scotia. Edited by A.K. Chatterjee and D.B. Clarke. Nova Scotia Department of Mines and Energy, Paper 85-3, pp. 233-248. 
Giles, P.S. and Chatterjee, A.K. 1986. Peraluminous granites of the Liscomb Complex. Nova Scotia Department of Mines and Energy, Tenth Annual Open House and Review of Activities. Programs and Summaries, pp. 83-89.

1987. Lower crustal xenocrysts and xenoliths in the Tangier dyke, eastern Meguma Zone, Nova Scotia. Nova Scotia Department of Mines and Energy, Report 87-5, pp. 85-88.

Graves, R.M. and Finck, P.W. 1988. The provenance of tills overlying the eastern part of the South Mountain Batholith, Nova Scotia. Maritime Sediments and Atlantic Geology, 24, pp. 61-70.

HAM, L.J. 1988. Preliminary geological map of Windsor, NTS sheets $21 \mathrm{~A} / 16$ (west half) and part of $21 \mathrm{H} / 01$. Nova Scotia Department of Mines and Energy, Open File Map 88-015. scale $1: 50,000$.

1989. Preliminary geological map of Digby, NTS sheet 21 A/12. Nova Scotia Department of Mines and Energy, Open File Map 89-015, scale 1:50,000.

HAM, L.J. and Horne, R.J. 1987. Bedrock geological map of Windsor NTS sheet 21A/16 (east half). Nova Scotia Department of Mines and Energy, Map 87-7, scale 1:50,000.

Ham, L.J. and MacDonald, M.A. 1991. Preliminary geological map of Wentworth Lake, NTS sheet 21 A/04. Nova Scotia Department of Mines and Energy, Open File Map 89-011, scale $1: 50,000$.

Ham, L.J., Marsh, S.W., Corey, M.C., Horne, R.J., and MacDonald, M.A. 1989. Lithogeochemistry of the eastern portion of the South Mountain Batholith, Nova Scotia. Nova Scotia Department of Mines and Energy, Open File Report 89-001, 65 p.

Ham, L.J., Corey, M.C., Horne, R.J., and MacDonald, M.A. 1990. Lithogeochemistry of the western portion of the South Mountain Batholith, Nova Scotia. Nova Scotia Department of Mines and Energy, Open File Report 90-007, 31 p.

HARPER, C.L. 1988. On the nature of time in the cosmological perspective. Unpublished Ph.D. thesis, Oxford University, London, England, 508 p.

Horne, R.J. 1987. Preliminary geology map of New Germany NTS sheet $21 \mathrm{~A} / 10$. Nova Scotia Department of Mines and Energy, Open File Map 87-004, scale 1:50,000.

Horne, R.J. and Corey, M.C. 1991. Preliminary geological map of Kejimkujik Lake, NTS sheet 21A/06. Nova Scotia Department of Mines and Energy, Open File Map 89-013, scale $1: 50,000$.

Horne, R.J., Corey, M.C., Ham, L.J., and MacDonald, M.A. 1988. Primary and secondary structural features in the eastern portion of the South Mountain Batholith, southwestern Nova Scotia: implications for regional stress orientations during intrusion. Maritime Sediments and Atlantic Geology. 24. pp. 71-82.

- 1989. Lithogeochemical variation within the biotite-rich envelope rocks of the eastern South Mountain Batholith: implications for its intrusive and post-intrusive history. In Mines and Minerals Branch Report of Activities 1988, Part B. Edited by Y. Brown and D.R. MacDonald. Nova Scotia Department of Mines and Energy, Report 89-1, pp. 37-50.

Horne, R.J., MacDonald, M.A., Corey, M.C., and Ham, L.J. 1992. Structure and emplacement of the South Mountain Batholith, southwestern Nova Scotia. Atlantic Geology, 28, pp. 29-50.

Howie, R.D. and Barss, M.S. 1975. Upper Paleozoic rocks of the Atlantic Provinces, Gulf of St. Lawrence, and adjacent con- tinental shelf. In Offshore Geology of Eastern Canada. Geological Survey of Canada, Paper 74-30, 258 p.

IshinARA, S. 1977. The magnetite-series and ilmenite-series granitic rocks. Mining Geology, 27, pp. 293-305.

Kempster, R.M.F., Clarke, D.B., Reynolds, P.H., and ChatTERJEe, A.K. 1989. Late Devonian lamprophyric dykes in the Meguma Zone of Nova Scotia. Canadian Journal of Earth Sciences, 26, pp. 611-613.

KePPIE, J.D. (compiler) 1979. Geological map of the province of Nova Scotia. Nova Scotia Department of Mines and Energy map, scale 1:500,000.

KepPIE, J.D. and DallmeyeR, R.D. 1987. Dating transcurrent terrane accretion: an example from the Meguma and Avalon composite terranes in the northern Appalachians. Tectonics, 6. pp. 831-847.

Kontak, D.J. 1990. The East Kemptville topaz-muscovite leucogranite, Nova Scotia: I. Geological setting and whole rock geochemistry. Canadian Mineralogist, 28, pp. 787-825.

Kontak, D.J. and Chatterjee, A.K. In press. The East Kemptville tin deposit, Yarmouth County, Nova Scotia III. A Pb isotope study of the leucogranite and mineralized greisen: Evidence for a $366 \mathrm{Ma}$ metallogenic event. Canadian Journal of Earth Sciences, 29.

Kontak, D.J. and Corey, M.C. 1988. Metasomatic origin for spessartine-rich garnet in the South Mountain Batholith, Nova Scotia. Canadian Mineralogist, 26, pp. 315-334

Kontak, D.J. and Cormier, R.F. 1991. A Rb/Sr geochronological study of the East Kemptville leucogranite, East Kemptville tin deposit, Yarmouth County, Nova Scotia: evidence for multiple tectono-thermal overprinting events. Canadian Journal of Earth Sciences, 28, pp. 209-224.

Kontak, D.J., Strong, D.F., and Kerrich, R. 1988. Crystalmelttfluid phase equilibria versus late-stage fluid-rock interaction in granitic rocks of the South Mountain Batholith, Nova Scotia: Whole rock geochemistry and oxygen isotope evidence. Maritime Sediments and Atlantic Geology, 24, pp. 97-110.

Kontak, D.J., Cormier, R.F., and Reynolds, P.H., and TAYlor, K. 1989. Preliminary results of $\mathrm{Rb} / \mathrm{Sr}$ and ${ }^{40} \mathrm{Ar} /{ }^{39} \mathrm{Ar}$ geochronological investigations, East Kemptville leucogranite, southwestern Nova Scotia: Evidence for a ca. $370 \mathrm{Ma}$ age of emplacement and multiple tectono-thermal overprinting events. In Mines and Minerals Branch Report of Activities 1989, Part A. Edited by D.R. MacDonald and K.A. Mills. Nova Scotia Department of Mines, Report 89-3, pp. 41-47.

Kontak, D.J., Chatterjee, A.K., Reynolds, P.H., and Taylor, K. 1990. $\mathrm{A}^{40} \mathrm{Ar} /{ }^{39} \mathrm{Ar}$ geochronological study of metamorphic and igneous rocks of the Liscomb Complex, southern Nova Scotia. Nova Scotia Department of Mines and Energy, Report 90-1, pp. 33-40.

Locothetis, J. 1985. Economic geology of the New Ross-Vaughan Complex. In Guide to the granites and mineral deposits of southwestern Nova Scotia. Edited by A.K. Chatterjee and D.B. Clarke. Nova Scotia Department of Mines and Energy, Paper 85-3, pp. 41-62.

MacDonald, M.A. 1985. A traverse through the southeastern part of the South Mountain Batholith: The granite geology of highway 103 between Halifax and Chester. In Guide to the granites and mineral deposits of southwestern Nova Scotia. Edited by A.K. Chatterjee and D.B. Clarke. Nova Scotia Department of Mines and Energy, Paper 85-3, pp. 15-26.

MacDonald, M.A. and Clarke, D.B. 1991. Use of nonparamet- 
ric ranking statistics to characterize magmatic and postmagmatic processes in the eastern South Mountain Batholith, Nova Scotia, Canada. Chemical Geology, 92, pp. 1-20.

MacDonald, M.A. and HaM, L.J. 1988. Preliminary geological map of Gaspereau Lake, NTS sheets 21 A/15 and part of 21H/ 02. Nova Scotia Department of Mines and Energy, Open File Map 88-016, scale 1:50,000.

1989a. Preliminary geological map of Weymouth, NTS sheet 21A/05. Nova Scotia Department of Mines and Energy, Open File Map 89-012, scale 1:50,000.

1989b. Preliminary geological map of Bridgetown, NTS sheet $21 \mathrm{~A} / 14$. Nov a Scotia Department of Mines and Energy, Open File Map 89-016, scale 1:50,000.

MacDonald, M.A. and Horne, R.J. 1987. Bedrock geological map of Halifax and Sambro NTS sheets 11D/12 and part of $11 \mathrm{D} / 05$. Nova Scotia Department of Mines and Energy, Map 87-6, scale 1:50,000.

1988. Petrology of the zoned, peraluminous Halifax pluton, south-central Nova Scotia. Maritime Sediments and Atlantic Geology, 24, pp. 33-46.

MacDonald, M.A., Corey, M.C., Ham, L.J., and Horne, R.J. 1987. The geology of the South Mountain Batholith: NTS sheets $21 \mathrm{~A} / 09,21 \mathrm{~A} / 10,21 \mathrm{~A} / 15$ and $21 \mathrm{~A} / 16$ (west). Nova Scotia Department of Mines and Energy, Report 87-1, pp. 107-128.

1988. South Mountain Batholith project: a progress report on bedrock mapping. Nova Scotia Department of Mines and Energy, Report 88-3, pp. 109-116.

McKenzie, C.B. 1974. Petrology of the South Mountain Batholith, western Nova Scotia. Unpublished M.Sc.thesis, Dalhousie University, Halifax, Nova Scotia, 164 p.

McKenzie, C.B. and Clar Ke, D.B. 1975. Petrology of the South Mountain Batholith, Nova Scotia. Canadian Journal of Earth Sciences, 12, pp. 1209-1218.

Muecke, G.K., Elias, P., and Reynolds, P.H. 1988. Hercynian/ Alleghanian overprinting of an Acadian Terrane: ${ }^{40} \mathrm{Ar} /{ }^{9} \mathrm{Ar}$ studies in the Meguma Zone, Nova Scotia, Canada. Chemical Geology, 73, pp. 153-167.

O'Reilly, G.A., Farley, E.J., and Charest, M.H. 1982. Metasomatic-hydrothermal mineral deposits of the New Ross-Mahone Bay area, Nova Scotia. Nova Scotia Department of Mines and Energy, Paper 82-2, $96 \mathrm{p}$.

O'Reilly, G.A., Corey, M.C., and ForD, K.L. 1988. The role of airborne gamma-ray spectrometry in bedrock mapping and mineral exploration: case studies from granitic rocks within the Meguma Zone, Nova Scotia. Maritime Sediments and Atlantic Geology, 24, pp. 47-60.

Reynolds, P.H., Zentilli, M., and Muecke, G.K. 1981. K-Ar and ${ }^{40} \mathrm{Ar} /{ }^{39} \mathrm{Ar}$ geochronology of granitoid rocks from southern Nova Scotia: its bearing on the geological evolution of the Meguma Zone of the Appalachians. Canadian Journal of Earth Sciences, 18, pp. 386-394.

Reynolds, P.H., Elias, P., Muecke, G.K., and Grist, A.M. 1987. Thermal history of the southwestern Meguma Zone, Nova Scotia, from an ${ }^{40} \mathrm{Ar} /{ }^{39} \mathrm{Ar}$ and fission track dating study of intrusive rocks. Canadian Journal of Earth Sciences, 24, pp. 1952-1965.
Richardson, J.M. 1988. Field and textural relationships of alteration and greisen-hosted mineralization at the East Kemptville tin deposit, Davis Lake Complex, southwest Nova Scotia. In Recent Advances in the Geology of Granite-Related Mineral Deposits. Edited by R.P. Taylor and D.F. Strong. Canadian Institute of Mining and Metallurgy, 39, pp. 265-279.

Richardson, J.M., Spooner, E.T.C., and McAuslan, D.A. 1982. The East Kemptville tin deposit, Nova Scotia: An example of a large tonnage, low grade, greisen-hosted deposit in the endocontact zone of a granite batholith. In Current Research, Part B, Geological Survey of Canada, Paper 82-1B, pp. 27. 32.

Richardson, J.M., Bell, K., Blenkinsop, J., and Watkinson, D.H. 1989. Rb-Sr age and geochemical distinctions between the Carboniferous tin-bearing Davis Lake complex and the Devonian South Mountain Batholith, Meguma Terrane, Nova Scotia. Canadian Journal of Earth Sciences, 26, pp. 2044 2061.

Ruffman, A. and Greenough, J.D. 1990. The Weekend dykes, a newly recognized mafic dyke swarm on the eastern shore of Nova Scotia, Canada. Canadian Journal of Earth Sciences, 27, pp. 644-648.

SMITH, P.K. 1985. Mylonitization and fluidized brecciation in southern Nova Scotia. In Mines and Minerals Branch Report of Activities 1984. Edited by K.A. Mills and J.L. Bates. Nova Scotia Department of Mines and Energy, Report 85-1, pp. 119-133.

Sмітн, T.E. 1974. The geochemistry of the granitic rocks of Halifax County, Nova Scotia. Canadian Journal of Earth Sciences, 11, pp. 650-656.

1979. The geochemistry and origin of the Devonian granitic rocks of southwest Nova Scotia. Geological Society of America Bulletin, 90, pp. 850-885.

Smith, T.E. and TUREK, A. 1976. Tin-bearing potential of some Devonian granitic rocks in southwest Nova Scotia. Mineralium Deposita, 11, pp. 234-245.

Smith, T.E., Peck, D., Huang, C.H., and Holm, P.E. 1986. A reappraisal of the alaskite/muscovite-biotite granite suite of Halifax County, Nova Scotia. Maritime Sediments and Atlantic Geology, 22, pp. 101-116.

Smitheringale, W.G. 1973. Geology of parts of Digby, Bridg. etown, and $\mathrm{G}$ aspereau Lake map areas, Nova Scotia. Geological Survey of Canada, Memoir 375, 78 p.

Streckeisen, A. 1976. To each plutonic rock its proper name. Earth Science Review, 12, pp. 1-33.

Strong, D.F. 1981. Ore deposit models - 5. A model for granophile mineral deposits. Geoscience Canada, 8, pp. 155-161.

TAYLOR, F.C. 1969. Geology of the Annapolis-St. Mary's Bay map-area, Nova Scotia. Geological Survey of Canada, Memoir $358,63 \mathrm{p}$.

White, A.J.R., Clemens, J.D., Holloway, J.R., Silver, L.T., ChAppell, B.W., and WALL, V.J. 1986. S-type granites and their probable absence in southwestern North America. Geology, 14, pp. 115-118.

Williams, H. and Hatcher, R.D. Jr. 1983. Appalachian suspect terranes. Geological Society of America, Memoir 158, pp. 33-53. 